\title{
Lack of population genetic structure and host specificity in the bat fly, Cyclopodia horsfieldi, across species of Pteropus bats in Southeast Asia
}

Kevin J Olival ${ }^{1,2,3^{*}}$, Carl W Dick ${ }^{4,5}$, Nancy B Simmons ${ }^{6}$, Juan Carlos Morales ${ }^{7}$, Don J Melnick ${ }^{3}$, Katharina Dittmar ${ }^{5,8}$, Susan L Perkins ${ }^{2}$, Peter Daszak ${ }^{1}$ and Rob DeSalle ${ }^{2}$

\begin{abstract}
Background: Population-level studies of parasites have the potential to elucidate patterns of host movement and cross-species interactions that are not evident from host genealogy alone. Bat flies are obligate and generally hostspecific blood-feeding parasites of bats. Old-World flies in the family Nycteribiidae are entirely wingless and depend on their hosts for long-distance dispersal; their population genetics has been unstudied to date.

Methods: We collected a total of 125 bat flies from three Pteropus species (Pteropus vampyrus, P. hypomelanus, and P. Iylei) from eight localities in Malaysia, Cambodia, and Vietnam. We identified specimens morphologically and then sequenced three mitochondrial DNA gene fragments (Col, Coll, cytB; 1744 basepairs total) from a subset of 45 bat flies. We measured genetic diversity, molecular variance, and population genetic subdivision $\left(\mathrm{F}_{\mathrm{ST}}\right)$, and used phylogenetic and haplotype network analyses to quantify parasite genetic structure across host species and localities.

Results: All flies were identified as Cyclopodia horsfieldi with the exception of two individuals of Eucampsipoda sundaica. Low levels of population genetic structure were detected between populations of Cyclopodia horsfieldi from across a wide geographic range $(\sim 1000 \mathrm{~km})$, and tests for isolation by distance were rejected. AMOVA results support a lack of geographic and host-specific population structure, with molecular variance primarily partitioned within populations. Pairwise $F_{\text {ST }}$ values from flies collected from island populations of Pteropus hypomelanus in East and West Peninsular Malaysia supported predictions based on previous studies of host genetic structure.

Conclusions: The lack of population genetic structure and morphological variation observed in Cyclopodia horsfieldi is most likely due to frequent contact between flying fox species and subsequent high levels of parasite gene flow. Specifically, we suggest that Pteropus vampyrus may facilitate movement of bat flies between the three Pteropus species in the region. We demonstrate the utility of parasite genetics as an additional layer of information to measure host movement and interspecific host contact. These approaches may have wide implications for understanding zoonotic, epizootic, and enzootic disease dynamics. Bat flies may play a role as vectors of disease in bats, and their competence as vectors of bacterial and/or viral pathogens is in need of further investigation.
\end{abstract}

Keywords: Bartonella, Connectivity, Diptera, Flying fox, Ectoparasite, Emerging infectious disease, Gene flow, Nipah virus, Nycteribiidae, Pathogens, Phylogeography

\footnotetext{
* Correspondence: olival@ecohealthalliance.org

${ }^{1}$ EcoHealth Alliance, New York, NY 10001, USA

${ }^{2}$ Sackler Institute for Comparative Genomics, American Museum of Natural History, New York, NY 10024, USA

Full list of author information is available at the end of the article
} 


\section{Background}

Intraspecific evolutionary studies of parasites can give insight into vector ecology, and uncover patterns of connectivity in host species populations not inferred by host genealogy alone $[1,2]$. In some cases, host and parasite population structure may be strongly congruent $[3,4]$. In other cases, host populations may be panmictic or genetically homogeneous, and parasite population structure can be used as a surrogate to identify cryptic population structure or infer host movement [5-8]. Alternatively, structured host populations may harbor unstructured parasite populations, which may suggest high levels of contact (i.e. sharing of parasites), but not mating, among host populations $[9,10]$. Congruence between host and parasite population structure will vary depending on the life-history traits and ecology of each species, but is generally expected when parasite species are highly host specific, lack free-living stages in their lifecycle, and when host and parasite both have limited dispersal $[1,11]$. Intraspecific genetic studies of ectoparasites are relatively uncommon in the literature, but there is a growing interest in using molecular data to elucidate parasite-host species interactions at the population level [11-13].

Bat flies (Diptera: Hippoboscoidea) are highly specialized, blood-feeding ectoparasites of bats. The monophyletic group comprises two families, Nycteribiidae and Streblidae, with the latter comprised of Old and New World clades [14]. Nycteribiid bat flies include 3 subfamilies, 12 genera and 275 described species; the subfamily Cyclopodiinae contains 4 genera and 62 species [15]. Flies in the genus Cyclopodia parasitize only bat species in the family Pteropodidae, and global distributions of the two groups closely coincide [16]. Cyclopodia horsfieldi occurs along with its primary host, Pteropus vampyrus, across Malaysia, Indonesia, and the Philippines and there is a recent record of the parasite from Megaerops niphanae (Pteropodidae: Cynopteriniae) in Vietnam [16,17]. Most bat fly species are highly host specific, and historical records of multiple host species are often erroneous and should be interpreted with caution $[18,19]$. In some cases the recorded geographic range of bat fly species is more limited than the host species range, for example Cyclopodia greeffi and its widespread host, Eidolon helvum in Africa [16]. Although less common, Cyclopodia species may exhibit oligoxeny, parasitizing two or more related host species, e.g. C. albertisi found on three Pteropus spp. in Australia and the islands of Papua New Guinea [16,20]. Marshall examined 44 species of nycteribiids from Malaysia and the New Hebrides and found 29 were monoxenous, parasitizing only one host species, and 15 were oligoxenous [21]. Mechanisms that should be expected to promote host switching in bat flies include a high degree of spatial overlap of host species at the geographic and habitat scale and mixed species roosting, as bat fly pupation takes place off the host and within the roost structure itself $[19,22]$. However, an extensive study of bat flies in the Neotropics found that specificity of flies followed the taxonomy of hosts, not their ecological associations or polyspecific roosting habits [23]. From an evolutionary perspective, colonizing multiple host species may be an advantageous strategy as this would increase the effective "habitat" available for parasite species to occupy [2].

Nycteribiid bat flies have highly-derived morphological characteristics including winglessness, dorsoventrally flattened bodies, and heads that fold against the thorax when at rest [15]. Bat flies have a unique reproductive strategy, whereby females develop their eggs internally nourished by "milk" glands, and a single prepupa ( $3^{\text {rd }}$ instar larva) is deposited on the roost substrate. While very little information on nycteribiid biology is available, for Eucampsipoda teneral adults typically emerge within 20-25 days of deposition to seek a new host and feed, and reach sexual maturity in 5-6 days after emergence [24]. Adult flies will die of starvation within 24 hours after being separated from their host. While most streblid species have wings as adults, nycteribiids are wingless and largely dependent on their hosts for dispersal [25].

Large fruit bats in the genus Pteropus, commonly called flying foxes, are host to Cyclopodia species. Three species of Pteropus -- P. vampyrus, P. lylei, and $P$. hypomelanus -- are broadly sympatric across most of their geographic ranges in Southeast Asia and from what is known, share similar habitat requirements and dietary preference. The Large Flying Fox, P. vampyrus, has a wide geographic range from southern Vietnam, Cambodia, Thailand, Malaysia, Philippines, and through much of Indonesia to East Timor [26]. Lyle's Flying Fox, P. lylei, has a narrower range and is found in southern Vietnam, Cambodia, and Thailand [27]. The Variable Flying Fox, P. hypomelanus, has a wide and fragmented distribution throughout the Indo-Australian region where it is primarily found on small off-shore islands, often roosting near the coast [28]. All three of these Pteropus species can be differentiated in the field using morphological characters and measurements, including forearm length, body mass, size and shape of the pinna, and fur on the dorsal tibia [29,30]. Molecular data support the grouping of these three Pteropus species into two distinct clades; Pteropus vampyrus and P. lylei are part of the same clade, but are not sister taxa to one another [31].

Previous molecular investigations of bat flies have primarily focused on higher-level systematics [14,32]. To our knowledge only two studies have examined the 
population genetic structure of bat flies, both investigating Trichobius major (Streblidae) parasitizing Myotis velifer from the USA (Kansas, Oklahoma, and Texas) using mtDNA [33] and amplified fragment length polymorphism of nuclear DNA [34]. Wilson et al. [33] observed only a single mtDNA haplotype for all $T$. major sampled, and Lack et al. [34] identified nDNA variation, but not corresponding to geographic locality.

Here we characterize the genetic and taxonomic diversity and host specificity of bat flies from three species of Southeast Asian fruit bats in the genus Pteropus and examine the population genetic structure of Cyclopodia horsfieldi across multiple countries using three mitochondrial DNA markers. We discuss these results with respect to host population structure and gene flow, and disease ecology and transmission.

\section{Methods}

\section{Specimen collection}

We collected bat flies from three species of flying fox (Pteropus hypomelanus, P. vampyrus, and P. lylei) from localities across Southeast Asia (Figure 1, Table 1). In Malaysia, canopy mist nets were deployed near diurnal roosting trees or nearby feeding sites, and bats were immediately removed upon capture and held individually in cloth bags for $\sim 1 \mathrm{hr}$ before sampling. Bats were anesthetized using medetomidine/ketamine $(0.025 / 2.5 \mathrm{mg} /$ $\mathrm{kg}$ ) administered intramuscularly or were restrained without anesthesia to collect ectoparasites and wing biopsies for host DNA [35]. Bat flies were collected with forceps by examining the pelage of anesthetized or restrained bats, and placed directly in 95\% ethanol for preservation. All bats were handled and sampled in accordance with IACUC protocol (\#AAAA3272) from Columbia University. GPS coordinates were recorded for all sampling localities at the point of capture, although in Vietnam and Cambodia local hunters captured bats alive in mist nets near feeding sites and the exact roost localities were not known but likely within $50 \mathrm{~km}$ of the sampling site. All bats were marked, photographed, and released at the site of capture except for individuals of $P$. lylei and P. vampyrus from Vietnam which were

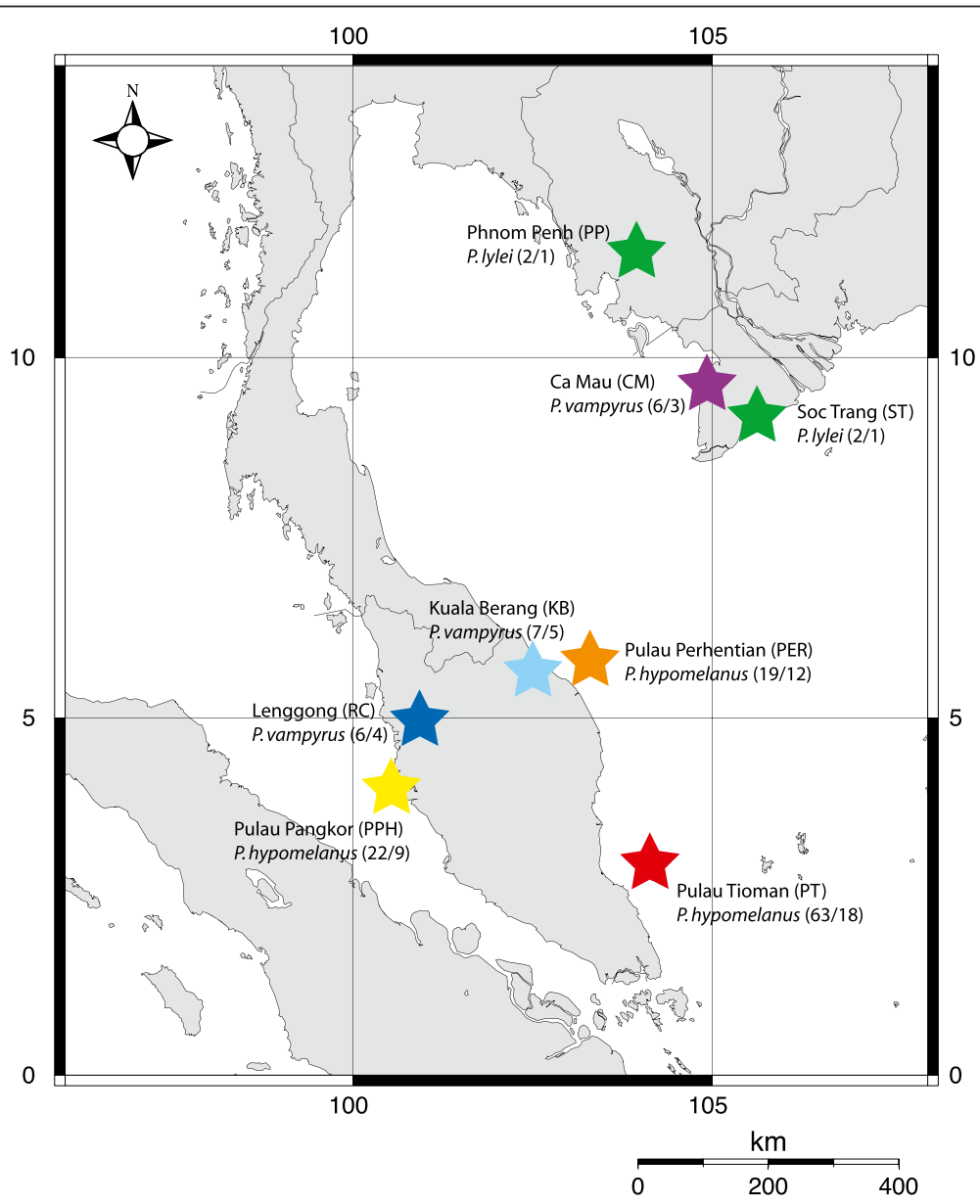

Figure 1 Sampling localities for Cyclopodia horsfieldi (with total flies collected/sequenced) from three Pteropus species in Southeast Asia. 
Table 1 Bat fly specimens examined, host species, sampling locations, and genes sequenced

\begin{tabular}{|c|c|c|c|c|c|c|c|c|c|c|c|c|}
\hline Bat ID & \# Flies coll. & Fly ID & Date collected & Fly Morph. ID & Host spp. & Sampling locality & Country & GPS Lat (North) & GPS Long (East) & CytB & Col & Coll \\
\hline $\mathrm{PPH01}$ & 2 & PPH01 & 25-Feb-06 & C. horsfieldi & P. hypomelanus & Pulau Pangkor & Malaysia & $04.23593^{\circ}$ & $100.54056^{\circ}$ & 1 & 1 & 1 \\
\hline $\mathrm{PPHO2}$ & 2 & PPH02 & 25-Feb-06 & C. horsfieldi & P. hypomelanus & Pulau Pangkor & Malaysia & $04.23593^{\circ}$ & $100.54056^{\circ}$ & 1 & 1 & 1 \\
\hline $\mathrm{PPH} 03$ & 3 & PPH03 & 25-Feb-06 & C. horsfieldi & P. hypomelanus & Pulau Pangkor & Malaysia & $04.23593^{\circ}$ & $100.54056^{\circ}$ & 1 & 1 & 1 \\
\hline $\mathrm{PPHO4}$ & 2 & PPH04 & 25-Feb-06 & C. horsfieldi & P. hypomelanus & Pulau Pangkor & Malaysia & $04.23593^{\circ}$ & $100.54056^{\circ}$ & 1 & 1 & 1 \\
\hline PPH06 & 2 & PPH06 & 25-Feb-06 & C. horsfieldi & P. hypomelanus & Pulau Pangkor & Malaysia & $04.23593^{\circ}$ & $100.54056^{\circ}$ & 1 & 1 & 1 \\
\hline $\mathrm{PPH} 08$ & 2 & PPH08 & 26-Feb-06 & C. horsfieldi & P. hypomelanus & Pulau Pangkor & Malaysia & $04.23593^{\circ}$ & $100.54056^{\circ}$ & 1 & 1 & 1 \\
\hline PPHO9 & 4 & PPH09 & 26-Feb-06 & C. horsfieldi & P. hypomelanus & Pulau Pangkor & Malaysia & $04.23593^{\circ}$ & $100.54056^{\circ}$ & 1 & 1 & 1 \\
\hline $\mathrm{PPH} 10$ & 2 & PPH10 & 26-Feb-06 & C. horsfieldi & P. hypomelanus & Pulau Pangkor & Malaysia & $04.23593^{\circ}$ & $100.54056^{\circ}$ & 1 & 1 & 1 \\
\hline $\mathrm{PPH} 12$ & 3 & PPH12 & 26-Feb-06 & C. horsfieldi & P. hypomelanus & Pulau Pangkor & Malaysia & $04.23593^{\circ}$ & $100.54056^{\circ}$ & 1 & 1 & 1 \\
\hline PER1 & 1 & PER01 & 2-May-07 & C. horsfieldi & P. hypomelanus & Pulau Perhentian & Malaysia & $05.90405^{\circ}$ & $102.74359^{\circ}$ & 1 & 1 & 1 \\
\hline PER2 & 2 & PER02 & 2-May-07 & C. horsfieldi & P. hypomelanus & Pulau Perhentian & Malaysia & $05.90405^{\circ}$ & $102.74359^{\circ}$ & 1 & - & 1 \\
\hline PER3 & 1 & PER03 & 3-May-07 & C. horsfieldi & P. hypomelanus & Pulau Perhentian & Malaysia & $05.90405^{\circ}$ & $102.74359^{\circ}$ & 1 & 1 & 1 \\
\hline PER6 & 1 & PER06 & 3-May-07 & C. horsfieldi & P. hypomelanus & Pulau Perhentian & Malaysia & $05.90405^{\circ}$ & $102.74359^{\circ}$ & 1 & 1 & 1 \\
\hline PER7 & 1 & PER07 & 3-May-07 & C. horsfieldi & P. hypomelanus & Pulau Perhentian & Malaysia & $05.90405^{\circ}$ & $102.74359^{\circ}$ & 1 & 1 & 1 \\
\hline PER8 & 2 & PER08 & 3-May-07 & C. horsfieldi & P. hypomelanus & Pulau Perhentian & Malaysia & $05.90405^{\circ}$ & $102.74359^{\circ}$ & 1 & 1 & 1 \\
\hline PER9 & 1 & PER09 & 4-May-07 & C. horsfieldi & P. hypomelanus & Pulau Perhentian & Malaysia & $05.90405^{\circ}$ & $102.74359^{\circ}$ & 1 & 1 & 1 \\
\hline PER10 & 1 & PER10 & 4-May-07 & C. horsfieldi & P. hypomelanus & Pulau Perhentian & Malaysia & $05.90405^{\circ}$ & $102.74359^{\circ}$ & 1 & 1 & 1 \\
\hline PER11 & 2 & PER11 & 4-May-07 & C. horsfieldi & P. hypomelanus & Pulau Perhentian & Malaysia & $05.90405^{\circ}$ & $102.74359^{\circ}$ & 1 & 1 & 1 \\
\hline PER12 & 2 & PER12 & 4-May-07 & C. horsfieldi & P. hypomelanus & Pulau Perhentian & Malaysia & $05.90405^{\circ}$ & $102.74359^{\circ}$ & 1 & 1 & 1 \\
\hline PER13 & 2 & PER13 & 4-May-07 & C. horsfieldi & P. hypomelanus & Pulau Perhentian & Malaysia & $05.90405^{\circ}$ & $102.74359^{\circ}$ & 1 & 1 & 1 \\
\hline PER14 & 2 & PER14 & 4-May-07 & C. horsfieldi & P. hypomelanus & Pulau Perhentian & Malaysia & $05.90405^{\circ}$ & $102.74359^{\circ}$ & 1 & 1 & 1 \\
\hline PER15 & 1 & PER15 & 4-May-07 & C. horsfieldi & P. hypomelanus & Pulau Perhentian & Malaysia & $05.90405^{\circ}$ & $102.74359^{\circ}$ & - & - & - \\
\hline 711041 & 1 & PT01 & 11-Jul-04 & $n / a$ & P. hypomelanus & Pulau Tioman & Malaysia & $02.84334^{\circ}$ & $104.15935^{\circ}$ & 1 & - & - \\
\hline 7110410 & 2 & PT10 & 11-Jul-04 & C. horsfieldi & P. hypomelanus & Pulau Tioman & Malaysia & $02.84334^{\circ}$ & $104.15935^{\circ}$ & 1 & 1 & 1 \\
\hline 7110411 & 1 & PT11 & 11-Jul-04 & C. horsfieldi & P. hypomelanus & Pulau Tioman & Malaysia & $02.84334^{\circ}$ & $104.15935^{\circ}$ & 1 & 1 & 1 \\
\hline 7110412 & 1 & PT12 & 11-Jul-04 & C. horsfieldi & P. hypomelanus & Pulau Tioman & Malaysia & $02.84334^{\circ}$ & $104.15935^{\circ}$ & 1 & - & - \\
\hline 7110413 & 1 & PT13 & 11-Jul-04 & C. horsfieldi & P. hypomelanus & Pulau Tioman & Malaysia & $02.84334^{\circ}$ & $104.15935^{\circ}$ & 1 & 1 & 1 \\
\hline 711042 & 3 & PT02 & 11-Jul-04 & C. horsfieldi & P. hypomelanus & Pulau Tioman & Malaysia & $02.84334^{\circ}$ & $104.15935^{\circ}$ & - & - & - \\
\hline 711043 & 1 & PT03 & 11-Jul-04 & $n / a$ & P. hypomelanus & Pulau Tioman & Malaysia & $02.84334^{\circ}$ & $104.15935^{\circ}$ & - & - & - \\
\hline 711044 & 5 & PT04 & 11-Jul-04 & C. horsfieldi & P. hypomelanus & Pulau Tioman & Malaysia & $02.84334^{\circ}$ & $104.15935^{\circ}$ & 1 & 1 & 1 \\
\hline 711045 & 2 & РT05 & 11-Jul-04 & $n / a$ & P. hypomelanus & Pulau Tioman & Malaysia & $02.84334^{\circ}$ & $104.15935^{\circ}$ & - & - & - \\
\hline
\end{tabular}


Table 1 Bat fly specimens examined, host species, sampling locations, and genes sequenced (Continued)

\begin{tabular}{|c|c|c|c|c|c|c|c|c|c|c|c|c|}
\hline 711046 & 3 & PT06 & 11-Jul-04 & C. horsfieldi & P. hypomelanus & Pulau Tioman & Malaysia & $02.84334^{\circ}$ & $104.15935^{\circ}$ & - & - & - \\
\hline 711047 & 3 & PT07 & 11-Jul-04 & C. horsfieldi & P. hypomelanus & Pulau Tioman & Malaysia & $02.84334^{\circ}$ & $104.15935^{\circ}$ & - & - & - \\
\hline 711048 & 2 & РТ08 & 11-Jul-04 & C. horsfieldi & P. hypomelanus & Pulau Tioman & Malaysia & $02.84334^{\circ}$ & $104.15935^{\circ}$ & 1 & 1 & 1 \\
\hline 7120414 & 2 & PT14 & 12-Jul-04 & C. horsfieldi & P. hypomelanus & Pulau Tioman & Malaysia & $02.84334^{\circ}$ & $104.15935^{\circ}$ & - & - & - \\
\hline 7120415 & 3 & PT15 & 12-Jul-04 & C. horsfieldi & P. hypomelanus & Pulau Tioman & Malaysia & $02.84334^{\circ}$ & $104.15935^{\circ}$ & 1 & 1 & 1 \\
\hline 7120416 & 2 & PT16 & 12-Jul-04 & C. horsfieldi & P. hypomelanus & Pulau Tioman & Malaysia & $02.84334^{\circ}$ & $104.15935^{\circ}$ & 1 & 1 & 1 \\
\hline 7120417 & 2 & PT17 & 12-Jul-04 & C. horsfieldi & P. hypomelanus & Pulau Tioman & Malaysia & $02.84334^{\circ}$ & $104.15935^{\circ}$ & - & - & - \\
\hline 7120418 & 2 & PT18 & 12-Jul-04 & C. horsfieldi & P. hypomelanus & Pulau Tioman & Malaysia & $02.84334^{\circ}$ & $104.15935^{\circ}$ & 1 & 1 & 1 \\
\hline 7120419 & 2 & PT19 & 12-Jul-04 & C. horsfieldi & P. hypomelanus & Pulau Tioman & Malaysia & $02.84334^{\circ}$ & $104.15935^{\circ}$ & - & - & - \\
\hline 7120420 & 2 & PT20 & 12-Jul-04 & C. horsfieldi & P. hypomelanus & Pulau Tioman & Malaysia & $02.84334^{\circ}$ & $104.15935^{\circ}$ & - & - & - \\
\hline 7120421 & 2 & PT21 & 12-Jul-04 & C. horsfieldi & P. hypomelanus & Pulau Tioman & Malaysia & $02.84334^{\circ}$ & $104.15935^{\circ}$ & 1 & 1 & 1 \\
\hline 7120422 & 1 & PT22 & 12-Jul-04 & C. horsfieldi & P. hypomelanus & Pulau Tioman & Malaysia & $02.84334^{\circ}$ & $104.15935^{\circ}$ & - & - & - \\
\hline 7120423 & 1 & PT23 & 12-Jul-04 & C. horsfieldi & P. hypomelanus & Pulau Tioman & Malaysia & $02.84334^{\circ}$ & $104.15935^{\circ}$ & 1 & 1 & 1 \\
\hline 7120424 & 2 & РT24 & 12-Jul-04 & C. horsfieldi & P. hypomelanus & Pulau Tioman & Malaysia & $02.84334^{\circ}$ & $104.15935^{\circ}$ & 1 & 1 & 1 \\
\hline 7120425 & 2 & PT25 & 12-Jul-04 & C. horsfieldi & P. hypomelanus & Pulau Tioman & Malaysia & $02.84334^{\circ}$ & $104.15935^{\circ}$ & 1 & 1 & 1 \\
\hline 7120426 & 2 & PT26 & 12-Jul-04 & C. horsfieldi & P. hypomelanus & Pulau Tioman & Malaysia & $02.84334^{\circ}$ & $104.15935^{\circ}$ & 1 & 1 & 1 \\
\hline 7120427 & 3 & PT27 & 12-Jul-04 & C. horsfieldi & P. hypomelanus & Pulau Tioman & Malaysia & $02.84334^{\circ}$ & $104.15935^{\circ}$ & 1 & 1 & 1 \\
\hline 7120428 & 2 & PT28 & 12-Jul-04 & C. horsfieldi & P. hypomelanus & Pulau Tioman & Malaysia & $02.84334^{\circ}$ & $104.15935^{\circ}$ & 1 & 1 & 1 \\
\hline 7120429 & 2 & PT29 & 12-Jul-04 & C. horsfieldi & P. hypomelanus & Pulau Tioman & Malaysia & $02.84334^{\circ}$ & $104.15935^{\circ}$ & 1 & 1 & 1 \\
\hline 7120433 & 2 & РТ33 & 12-Jul-04 & C. horsfieldi & P. hypomelanus & Pulau Tioman & Malaysia & $02.84334^{\circ}$ & $104.15935^{\circ}$ & - & - & - \\
\hline 7120434 & 2 & РТ34 & 12-Jul-04 & $n / a$ & P. hypomelanus & Pulau Tioman & Malaysia & $02.84334^{\circ}$ & $104.15935^{\circ}$ & - & - & - \\
\hline 7120436 & 2 & РT36 & 12-Jul-06 & C. horsfieldi & P. hypomelanus & Pulau Tioman & Malaysia & $02.84334^{\circ}$ & $104.15935^{\circ}$ & - & - & - \\
\hline Rest1 & 2 & LYL1 & 4-Feb-06 & C. horsfieldi & P. lylei & Phnom Penh & Cambodia & $11.55815^{\circ}$ & $104.91740^{\circ}$ & 1 & 1 & 1 \\
\hline 155642 & 2 & LYL2 & 8-Jan-06 & C. horsfieldi & P. Iylei & Soc Trang & Vietnam & $09.57849^{\circ}$ & $105.97201^{\circ}$ & 1 & 1 & 1 \\
\hline 155657 & 2 & CM1 & 11-Jan-06 & C. horsfieldi & P. vampyrus & Ca Mau & Vietnam & $09.15258^{\circ}$ & $104.91347^{\circ}$ & 1 & 1 & 1 \\
\hline 155660 & 3 & $\mathrm{CM} 2$ & 12-Jan-06 & C. horsfieldi & P. vampyrus & Ca Mau & Vietnam & $09.15258^{\circ}$ & $104.91347^{\circ}$ & 1 & 1 & 1 \\
\hline 155661 & 1 & $\mathrm{CM} 3$ & 12-Jan-06 & C. horsfieldi & P. vampyrus & Ca Mau & Vietnam & $09.15258^{\circ}$ & $104.91347^{\circ}$ & 1 & 1 & 1 \\
\hline 701043 & 2 & $\mathrm{~KB} 1$ & 1-Jul-04 & C. horsfieldi & P. vampyrus & Kuala Berang & Malaysia & $05.07219^{\circ}$ & $103.01707^{\circ}$ & 1 & 1 & 1 \\
\hline 702041 & 1 & KB2 & 2-Jul-04 & C. horsfieldi & P. vampyrus & Kuala Berang & Malaysia & $05.07219^{\circ}$ & $103.01707^{\circ}$ & 1 & 1 & 1 \\
\hline 702043 & 1 & KB3 & 2-Jul-04 & $n / a$ & P. vampyrus & Kuala Berang & Malaysia & $05.07219^{\circ}$ & $103.01707^{\circ}$ & 1 & 1 & 1 \\
\hline 702044 & 1 & KB4 & 2-Jul-04 & C. horsfieldi & P. vampyrus & Kuala Berang & Malaysia & $05.07219^{\circ}$ & $103.01707^{\circ}$ & 1 & 1 & 1 \\
\hline
\end{tabular}


Table 1 Bat fly specimens examined, host species, sampling locations, and genes sequenced (Continued)

\begin{tabular}{|c|c|c|c|c|c|c|c|c|c|c|c|c|}
\hline 709041 & 2 & KB5 & 9-Jul-04 & E. sundaicum & P. vampyrus & Lenggong & Malaysia & $05.13051^{\circ}$ & $100.83254^{\circ}$ & 1 & 1 & 1 \\
\hline $\mathrm{RC} 14$ & 2 & $\mathrm{RC} 14$ & 9-Jul-04 & C. horsfieldi & P. vampyrus & Lenggong & Malaysia & $05.13051^{\circ}$ & $100.83254^{\circ}$ & 1 & 1 & 1 \\
\hline $\mathrm{RC} 24$ & 1 & $\mathrm{RC} 24$ & 8-Jul-04 & C. horsfieldi & P. vampyrus & Lenggong & Malaysia & $05.13051^{\circ}$ & $100.83254^{\circ}$ & 1 & 1 & 1 \\
\hline RC29 & 1 & RC29 & 8-Jul-04 & C. horsfieldi & P. vampyrus & Lenggong & Malaysia & $05.13051^{\circ}$ & $100.83254^{\circ}$ & 1 & 1 & 1 \\
\hline
\end{tabular}

GenBank accession numbers: CytB (KF273687 - KF273736); Col (KF273737 - KF273783); and Coll (KF273784 - KF273833).

Bat fly specimens examined, morphological ID, host species, collection locality name and coordinates, and genes sequenced for one randomly selected bat fly from each bat. 
collected as voucher specimens currently accessioned at the Institute for Ecology and Biological Resources, Hanoi, Vietnam. From July 2004-May 2007, a total of 125 bat flies were collected from 66 individuals of the three host species (Table 1). Fly specimens are currently accessioned at Western Kentucky University, State University of New York at Buffalo, and the American Museum of Natural History. Sampling was not evenly distributed across host species; 104 flies were collected from three populations of $P$. hypomelanus, 17 flies from $P$. vampyrus, and four flies from P. lylei.

\section{Laboratory methods}

DNA was extracted from one randomly selected fly per bat using a technique where 1-3 legs per fly were removed (allowing retention of fly voucher). Qiagen DNeasy tissue extraction kits were used per manufacturer's protocol with a $24 \mathrm{hr}$ tissue digestion, and two combined elutions of $50 \mathrm{ul}$ of Buffer $\mathrm{AE}$ warmed to $55^{\circ} \mathrm{C}$.

Bat flies were sequenced at three mtDNA genes, cytochrome B (cytB), cytochrome oxidase II (CoII), and cytochrome oxidase I $(\mathrm{CoI})$, that were expected to show genetic differences at the population level based on previous intraspecific studies of Diptera [36-39]. Published forward and reverse primers used to amplify each gene were as follows: for $c y t B$, A5 and B 1.1 [36]; for CoII, AtLEU and B-tLYS [40]; and for CoI LepF1 and LepR1 [41]. For the $c y t B$ and $C o I I$ genes, we used PuReTaq Ready-To-Go ${ }^{\text {TM }}$ PCR Beads (GE Healthcare) with $21 \mu \mathrm{l}$ of molecular grade $\mathrm{ddH}_{2} \mathrm{O}, 1 \mu \mathrm{l}$ of each primer [10 $\mathrm{mM}$ ], and $2 \mu$ of template DNA. PCR conditions for $c y t B$ were identical to those in Dittmar and Whiting (2003), and for the CoII PCR conditions were an initial denaturation period of $3 \mathrm{~min}$ at $94^{\circ} \mathrm{C}$, followed by 35 cycles of $94^{\circ} \mathrm{C}$ for $1 \mathrm{~min}, 47^{\circ} \mathrm{C}$ for $1 \mathrm{~min}$, and $74 \mathrm{C}$ for $1 \mathrm{~min}$, with a final extension at $74^{\circ} \mathrm{C}$ for $7 \mathrm{~min}$. PCR mix and cycling conditions for $\mathrm{CoI}$ followed Hebert et al. [41] although total reaction volume was reduced in half to $25 \mu \mathrm{l}$. Attempts to amplify the mtDNA control region were unsuccessful using primers and conditions from Oliveira et al. [42], multiple stutter bands were amplified and a single PCR product was never obtained for the control region. Negative controls were always included in PCR reactions to assess possible contamination.

PCR products were cleaned using Agencourt (Beverly, Massachusetts) AmPure magnetic beads, cycle sequenced with Big Dye v.3.0 terminator mix (Applied Biosystems, Inc., Foster City, California), and final DNA was precipitated using Agencourt CleanSeq magnetic beads. All sequencing was performed on an ABI 3730xl capillary sequencer (Applied Biosystems) at the Sackler Institute for Comparative Genomics at the American Museum of Natural History, New York. Sequences were edited in Sequencher v.4.6 and manually corrected for ambiguous base calls. Alignment of sequences was done using MAFFT v.6 using default parameters [43]. Aligned sequences were trimmed using MacClade 4.08 [44]. No insertions or deletions were present in sequences of any of the three genes.

\section{Phylogenetic and population genetic analyses}

Phylogenetic relationships and nucleotide/haplotype diversity were initially determined for each mtDNA gene fragment independently. As there was a paucity of variable and parsimony-informative sites for each marker alone, sequence data from the three mtDNA genes were concatenated for a total of 1744 bp for each specimen. Phylogenetic analyses on the pooled dataset were conducted using PAUP* for maximum parsimony (MP) analysis [45], RAxML v.7.0 for maximum likelihood (ML) analysis [46], and Mr. Bayes for Bayesian analysis [47]. Nodal support was evaluated with the nonparametric bootstrap method [48]. MP bootstrap analysis used 1000 replicates, TBR branch swapping, with a starting tree obtained by random stepwise addition and additional sequences added at random with 10 replicates. The optimum model for ML analysis was determined using Akaike's Information Criterion to be GTR + G using Modeltest v.3.7 [49]. Optimal evolutionary models did not differ by locus, and data were not partitioned. RAxML analysis of 1000 bootstrap runs beginning with a random seed, and user-defined outgroup, was implemented on the CIPRES Portal webserver found at http://www.phylo.org/sub_sections/portal/. Bayesian analysis was conducted using MrBayes version 3.2 [47], with data partitioned by gene. The GTR + gamma + i model of evolution was used with a flat prior for topologies, uniform priors on gamma and alpha parameters, an unconstrained exponential prior on branch lengths, and Dirichlet priors on all other parameters. A total of ten million generations were run, and convergence was assessed using AWTY [50]. Sequences obtained from Eucampsipoda sundaica (\#KB5) were used as an outgroup to Cyclopodia horsfieldi in all phylogenetic analyses because of its basal position within the Cyclopodiinae [14].

Aligned FASTA files were collapsed into variable sites and haplotypes for parsimony network reconstruction with the online tool FaBox 1.31 (http://users-birc.au.dk/ biopv/php/fabox/). Fifty-one bat flies were sequenced, but outgroup and individual flies that did not have complete sequences for all three genes were excluded in subsequent analyses (PER08, PER02, PT15, PT12, and KB1), leaving 45 individuals. Statistical parsimony networks, useful for inferring relationships among sequences that have recently diverged, were created using TCS v.1.21 [51]. Parsimony networks were explored using the default connection limit of $95 \%$, but due to one divergent haplotype in the network (RC24), final 
network was determined with a user-defined limit set to 19 steps. Haplotype (Hd) and nucleotide $(\pi)$ diversity [52] were calculated in DnaSP v.4.5 [53]. Pairwise $F_{S T}$ values were calculated in Arlequin using a method based on pairwise differences in sequence data, and statistical significance was assessed with 1000 permutations [54]. We tested for isolation by distance between $C$. horsfieldi populations from Malaysia only, using a Mantel test [55] with 1000 permutations implemented in the $\mathrm{R}$ package adegenet 1.3-6 [56]. All sequences are available on GenBank: CytB (KF273687 - KF273736); CoI (KF273737 KF273783); and CoII (KF273784 - KF273833).

Analysis of molecular variance (AMOVA), was used to test hypotheses regarding the partitioning of genetic variation for $C$. horsfieldi among host species, among sampling localities within host species, and among individuals within sampling localities [57]. AMOVA was conducted in Arlequin v.3.1 [58] using the standard haplotype format with statistical significance assessed by 1000 permutations.

\section{Results}

\section{Bat fly morphology and demography}

All bat fly specimens examined were all identified morphologically as Cyclopodia horsfieldi (Figure 2) with the exception of two individuals of Eucampsipoda sundaica [59] collected from a Pteropus vampyrus (\#0709041) from Kuala Berang, Malaysia (Table 1). Some intraspecific morphological variation was noted, including minor differences in counts of ctenidial spines on male sternite and counts of dorsal abdominal setae on the females, but no systematic character variation related to host species or geography was observed. The sex ratio of $C$. horsfieldi specimens examined was male-biased, $1.85 \hat{\jmath}$ to 1 . . We observed that most bats were parasitized by at least one fly, and that Pteropus hypomelanus individuals had higher numbers of parasites than $P$. vampyrus. Several $P$. vampyrus captured hosted no flies but this was very rarely observed for $P$. hypomelanus. Many $P$. hypomelanus examined harbored $4+$ flies per individual (Figure 3); and some individuals had 10+ flies. Unfortunately, bats were not exhaustively sampled for flies and the number of fly specimens collected was generally limited to a few flies per bat regardless of parasite load, and quantitative data on intensity of infestation was not collected. The number of bat flies collected from each host was not significantly different (at the $\mathrm{p}<0.05$ level) between $P$. vampyrus and $P$. hypomelanus using both a standard $t$-test $(\mathrm{t}=-1.85 ; \mathrm{df}=13.8 ; \mathrm{p}$-value $=0.085)$ and Mann-Whitney test $(\mathrm{W}=176.5$; $\mathrm{p}$-value $=0.066)$. We also inadvertently collected Neolaelaps spinosa (Acari: Mesostigmata) mites as we removed individual flies with forceps. These mites appear to be phoretic with bat flies

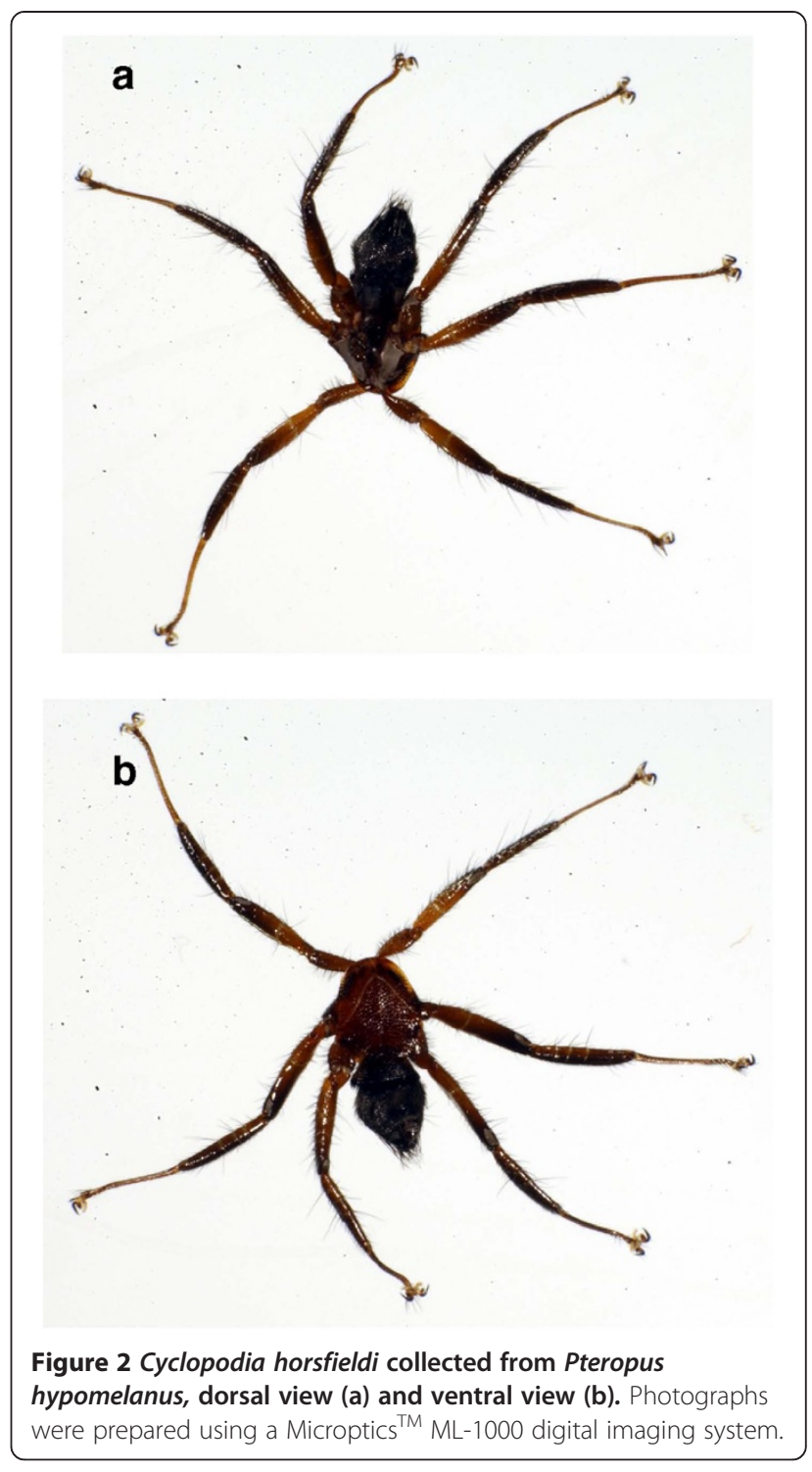

[60], a relationship that has been documented with mites and other dipteran species [61-63].

\section{Mitochondrial sequence variation, Cyclopodia horsfieldi}

Average nucleotide diversity for the combined $C$. horsfieldi mtDNA dataset (3 gene fragments, $1744 \mathrm{bp}$ ) was $0.002 \pm .0004$ (Table 2); comparable to values found in other Dipteran species [64-66]. The gene fragment length (base pairs, bp) and variable/parsimony informative sites for each gene segment were as follows: CoI (702bp, 11/5), CoII (678bp, 11/2), and cytB (364bp, $8 / 1)$. There was an overall high amount of haplotype diversity across all markers and specimens (0.903 \pm .026). Although sample sizes were limited, overall nucleotide and haplotype diversity were both higher for $C$. horsfieldi individuals from Pteropus vampyrus $(\pi=0.0042 \pm 0.0017, \quad h d=0.972 \pm 0.064) \quad$ compared to 


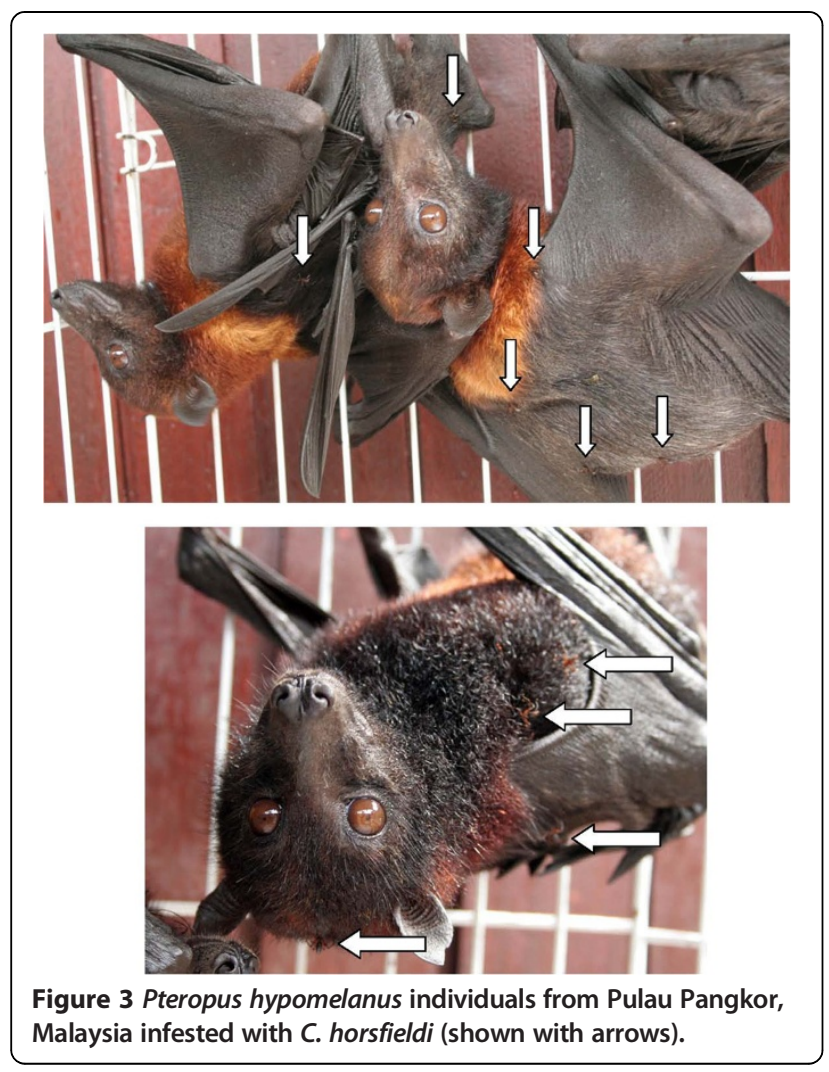

P. hypomelanus $(\pi=0.0014 \pm 0.00009$, hd $=0.861 \pm 0.042)$ (Table 2). Cyclopodia horsfieldi individuals from Pteropus hypomelanus on Pulau Pangkor had the lowest haplotype diversity of any population $(0.417 \pm 0.191)$, which corresponded with the smallest host population census size ( $\mathrm{n}=200$ bats). Total A-T content was uniformly high for all sequences (77.3\%), as is common in other insect mitochondrial genomes $[67,68]$. Summary of base frequencies across the complete dataset of 51 sequenced fly individuals were: $\mathrm{A}=0.3546, \mathrm{C}=0.1196$, $\mathrm{G}=0.1006$, and $\mathrm{T}=0.4251$.

\section{Population genetic structure, Cyclopodia horsfieldi}

Phylogenetic analyses of the combined mtDNA data set using ML (Figure 4) and MP (Figure 5) showed little resolution of population genetic structure for $C$. horsfieldi sampled across sites in Southeast Asia. No significant population structure that corresponded to either geography or host species was detected in any of the analyses (Figures 4, 6, 7). Despite an almost complete lack of resolution, some flies from geographically distant areas formed clades with greater than 50\% support in the MP tree (e.g. PT13, KB4, and CM3, from Peninsular Malaysia and Vietnam), also evident in the Bayesian tree (Figure 6). Bat flies collected from Pualu Pangkor (PPH), off the west coast of Peninsular Malaysia, appear to be distinct in the haplotype network (Figure 7, yellow), but several individuals shared identical haplotype sequences with flies collected $300 \mathrm{~km}$ away on the east coast of Malaysia from Pulau Perhentian (PER) (Figure 7). The most genetically divergent bat fly individual, RC24, was a male morphologically indistinguishable from all the other Cyclopodia horsfieldi specimens.

Despite an overall lack of geographic structure observed in phylogenetic and haplotype network analyses, pairwise $\mathrm{F}_{\mathrm{ST}}$ values for fly populations from Peninsular Malaysia fit a priori predictions based on gene flow of their Pteropus hosts [69]. Significant pairwise $\mathrm{F}_{\mathrm{ST}}$ values were observed between Cyclopodia horsfieldi sampled from Pteropus hypomelanus from western (PPH) vs. eastern (PER, PT) island populations (Table 3), suggesting some limits to parasite gene flow between these islands. Similarly, average pairwise $\mathrm{F}_{\mathrm{ST}}$ between $P$. vampyrus and the western $P$. hypomelanus population $(\mathrm{PPH})$ was significant and high $\left(\mathrm{F}_{\mathrm{ST}}=0.443\right)$ (Table 3). In contrast, pairwise $\mathrm{F}_{\mathrm{ST}}$ values between flies collected from the two western island $P$. hypomelanus populations were low and non-significant, as were $\mathrm{F}_{\mathrm{ST}}$ values between bat flies from $P$. vampyrus vs. eastern $P$. hypomelanus populations (PER, PT) (Table 3). The mantel test for geographic isolation by distance was rejected $(\mathrm{p}=0.373)$. The

Table 2 Nucleotide and haplotype diversity for Cyclopodia horsfieldi by host species and locality

\begin{tabular}{llllll}
\hline Host spp./locality & \# of Sequences & \# of Haplotypes & Haplotype diversity \pm SD & \# Variable sites & Nucleotide diversity \pm SD \\
\hline P. vampyrus (Malaysia) & 6 & 6 & $1.0 \pm 0.096$ & 23 & $0.0053 \pm 0.002$ \\
P. vampyrus (Vietnam) & 3 & 3 & $1.0 \pm 0.272$ & 6 & $0.0023 \pm 0.001$ \\
P. vampyrus (ALL) & 9 & 8 & $0.972 \pm 0.064$ & 25 & $0.0042 \pm 0.001$ \\
P. hypomelanus (PT) & 14 & 8 & $0.912 \pm 0.049$ & 7 & $0.0012 \pm 0.000$ \\
P. hypomelanus (PPH) & 9 & 3 & $0.417 \pm 0.191$ & 2 & $0.0003 \pm 0.000$ \\
P. hypomelanus (PER) & 10 & 6 & $0.867 \pm 0.085$ & 8 & $0.0019 \pm 0.000$ \\
P. hypomelanus (ALL) & 34 & 12 & $0.861 \pm 0.042$ & 11 & $0.0014 \pm 0.000$ \\
P. lylei (PP and ST) & 2 & 2 & $1.000 \pm 0.500$ & 4 & $0.0023 \pm 0.001$ \\
TOTAL & 45 & 17 & $0.903 \pm 0.026$ & 29 & $0.0020 \pm 0.000$
\end{tabular}

Data shown only for individuals ( $n=45$ ) with complete combined mtDNA dataset of Col, Coll, cytB (1744 bp). 


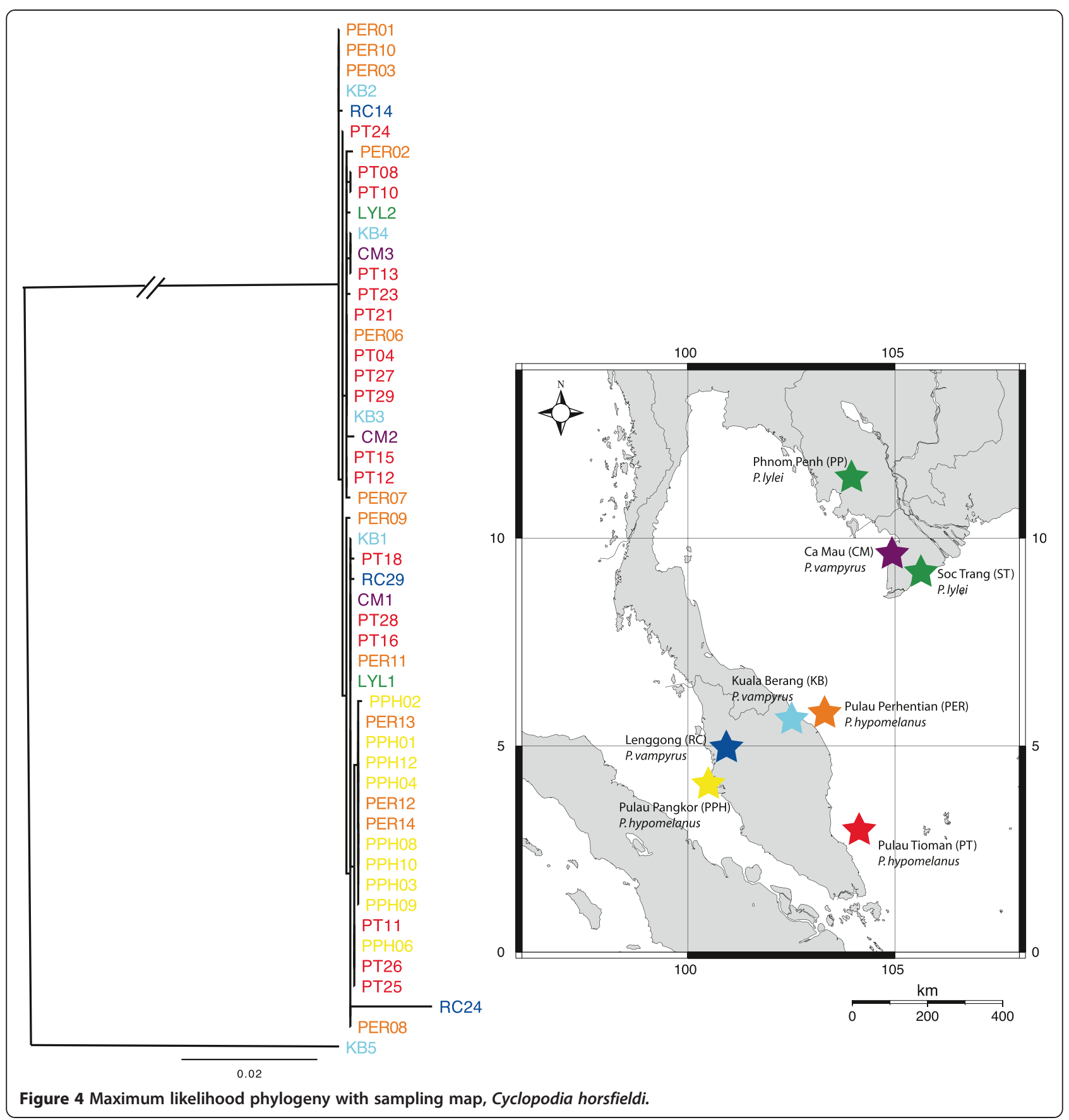

relationship between Pteropus hypomelanus $\mathrm{F}_{\mathrm{ST}}$ values and $\mathrm{F}_{\mathrm{ST}}$ from Cyclopodia horsfieldi flies collected from the same bat populations was strong $(\mathrm{r}=0.971)$ but nonsignificant in a randomized mantel test $(\mathrm{p}=0.34)$.

AMOVA results support a lack of geographic and host-specific population genetic structure in Cyclopodia horsfieldi (Table 4). Molecular variance was primarily partitioned within populations $(77.3 \%)$, not between geographic localities within host species $(22.3 \%)$ or between host species (0.4\%, not significant).

\section{Discussion}

Host specificity

Morphological and molecular species identification revealed that one fly species, Cyclopodia horsfieldi, parasitized all three Pteropus host species sampled from Malaysia, Vietnam and Cambodia. The only exceptions were two individuals of Eucampsipoda sundaica collected from an individual Pteropus vampyrus in Peninsular Malaysia. Minor morphological differences were observed among individuals of Cyclopodia horsfieldi, but 


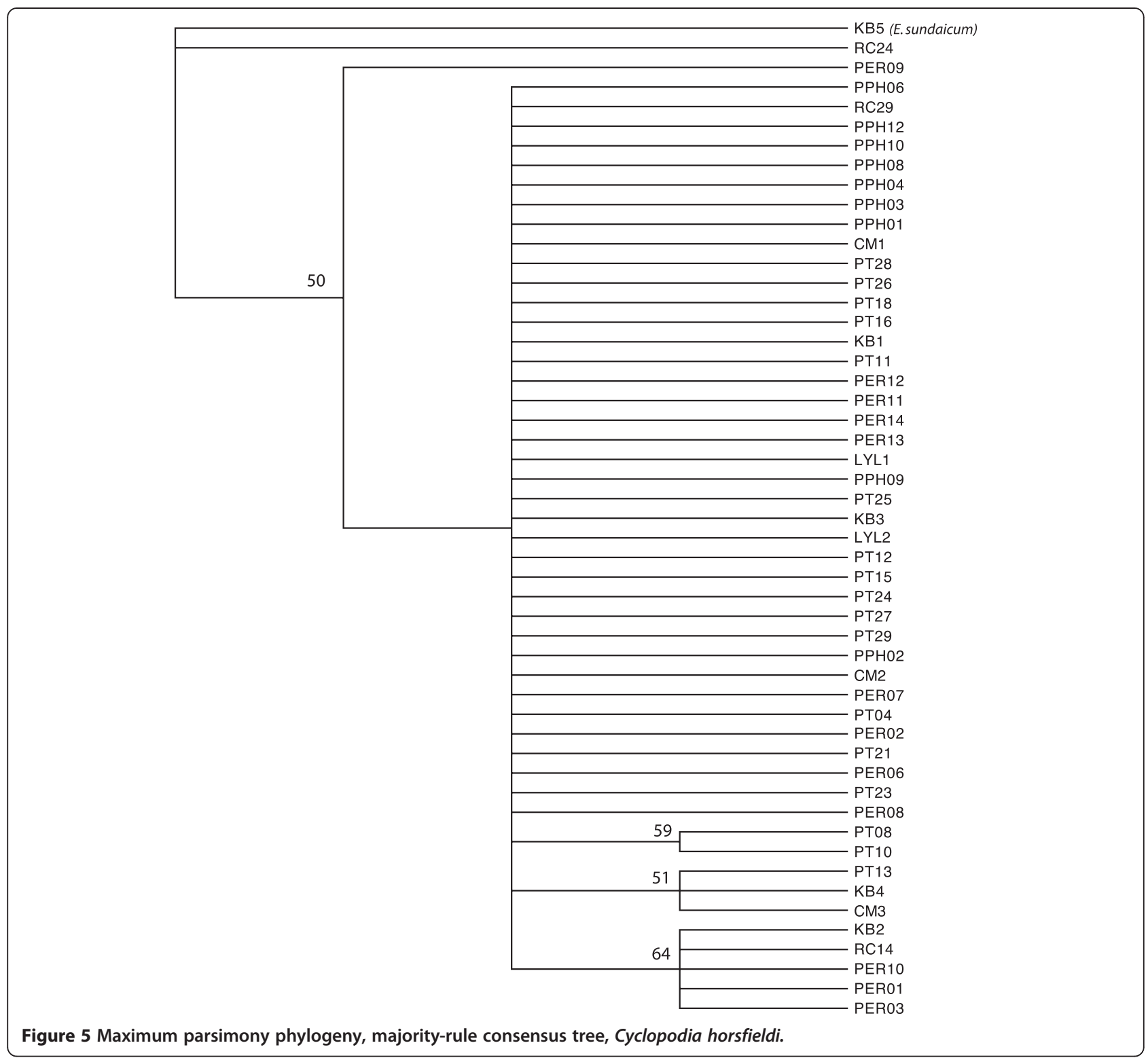

these did not correlate with sampling locality or host species, and the lack of systematic morphological variation is supported by a similar lack of geographic or host-specific population genetic structure. The sex ratio of the bat flies we randomly sampled was male-biased. This observation agrees with previous reports of excess males in bat fly populations, and may be caused by grooming mortality patterns [70] or the diurnal activity of female flies during larviposition [71].

Experimental studies have shown that some bat flies exhibit behavioral preference towards their primary host over congeneric and confamilial species [72]. However, we observe a natural case of parasite oligoxeny among three bat species in Southeast Asia, which has also been documented in Cyclopodia spp. from flying foxes in Australia
[16]. Oligoxeny is more likely in hosts that share geographic and habitat niches and/or co-roost at the same sites, and it appears to be an evolutionary advantageous strategy for an ectoparasite [2]. Our results suggest that co-mingling of Pteropus spp. in Southeast Asia is more common than previously assumed. On occasion, Pteropus vampyrus/P.lylei and P. vampyrus/P. hypomelanus coroosting has been observed in the same trees in Ca Mau, Vietnam and Pulau Langkawi, Malaysia, respectively [69]; and similar observations have been made in Thailand (P. Duengkae, per. comm.). It is also possible that these species could be sharing bat fly parasites without simultaneous occupation of the same roost, i.e. sequential use of a roosting site within a 2-3 week window where flies may emerge from metamorphosis on the roost substrate. 


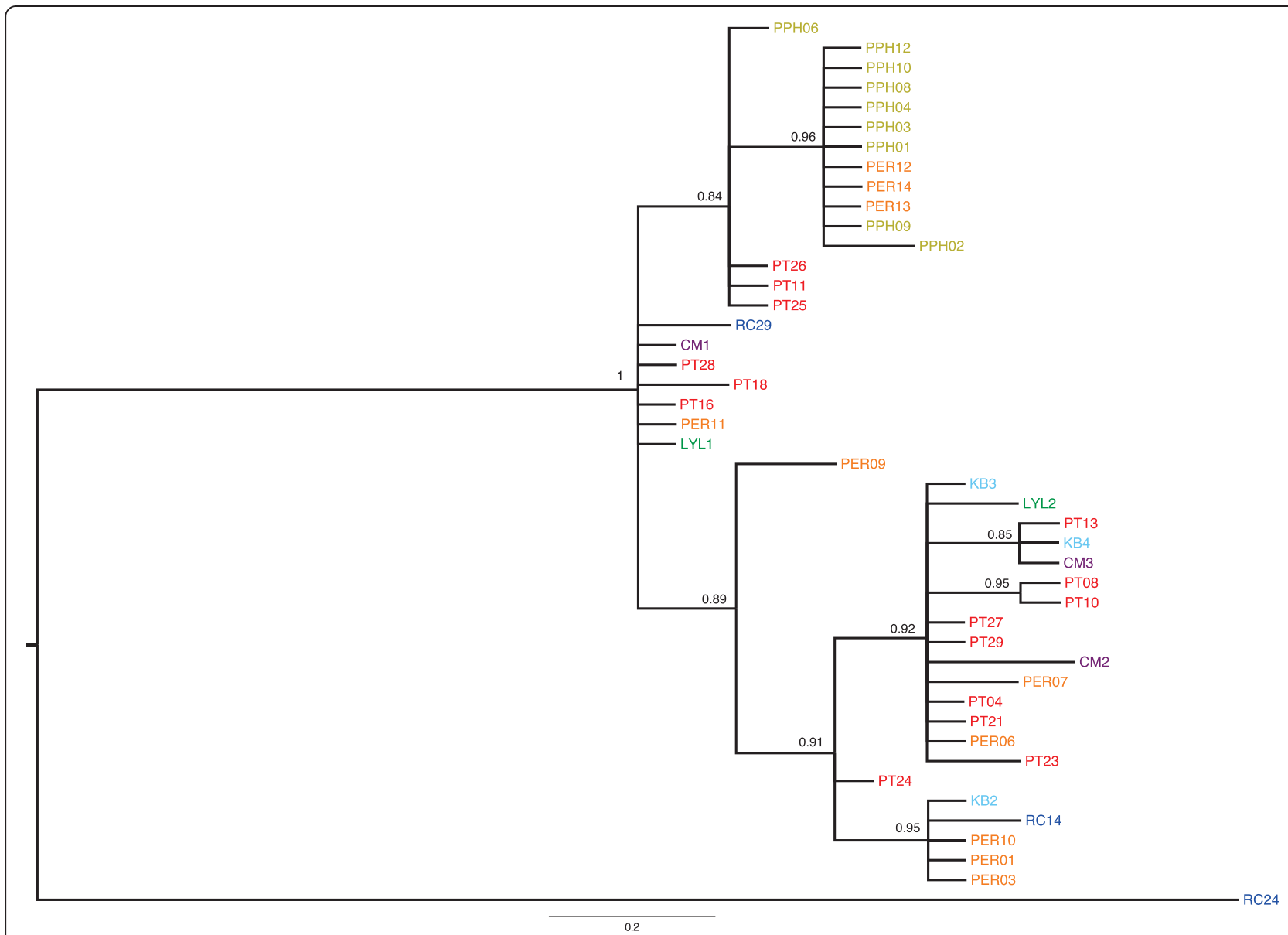

Figure 6 Bayesian phylogeny Cyclopodia horsfieldi using concatenated dataset, GTR + gamma $+\mathrm{i}$ model of evolution partitioned by gene, ten million generations, and no outgroup.

The presence of Eucampsipoda sundaica flies found on a Pteropus vampyrus individual may represent a case of host-switching, which would suggest contact and ecological overlap between other fruit bat species in Peninsular Malaysia. Eucampsipoda sundaica is the sole ectoparasite of the Dawn bat, Eonycteris spelaea [24], although there are previous records of this species from Cynopterus sphinx in India, Pteropus in Myanmar, and Rousettus amplexicatus from the Philippines $[59,73]$. Also, we found one genetically divergent bat fly, RC24, to be an outlier in haplotype network and phylogenetic analyses. This fly was morphologically indistinguishable from the other Cyclopodia horsfieldi examined, but could possibly represent a male of the sister species, C. sykesii [16]. C. sykesii is primarily associated with Pteropus giganteus from South Asia [16], and thus could possibly represent a case of host switching by secondary contact between these flying fox species. More fly specimens from $P$. vampyrus should be sampled and examined to confirm the rarity of these results.

\section{Comparative host-parasite population structure}

Overall, we found that populations of Cyclopodia horsfieldi lacked population genetic structure across geographically distant sites and host species in Southeast Asia. However, pairwise $F_{S T}$ values between some fly populations, particularly from Pteropus hypomelanus, corroborate expectations of reduced gene flow based on the population genetics of their flying fox hosts [69]. Olival [69] found that island populations of $P$. hypomelanus were significantly differentiated at mtDNA markers from East to West in Malaysia (e.g. $\mathrm{F}_{\mathrm{ST}}=0.95$, mtDNA control region), but had much higher levels of gene flow between the east coast islands $\left(\mathrm{F}_{\mathrm{ST}}=0.0\right.$ to 0.4). Here we observe a similar pattern for the parasite, Cyclopodia horsfieldi, with significant pairwise $\mathrm{F}_{\mathrm{ST}}$ values between flies from Pulau Pangkor off the west coast and Pulau Tioman $\left(\mathrm{F}_{\mathrm{ST}}=0.560\right)$ and Pulau Perhentian $\left(\mathrm{F}_{\mathrm{ST}}\right.$ $=0.435)$ off the east coast of Malaysia. In contrast, $\mathrm{F}_{\mathrm{ST}}$ values among flies from the two east coast islands were low and not significant $\left(\mathrm{F}_{\mathrm{ST}}=0.031\right)$. We also observed low and non-significant $\mathrm{F}_{\mathrm{ST}}$ values between mainland 


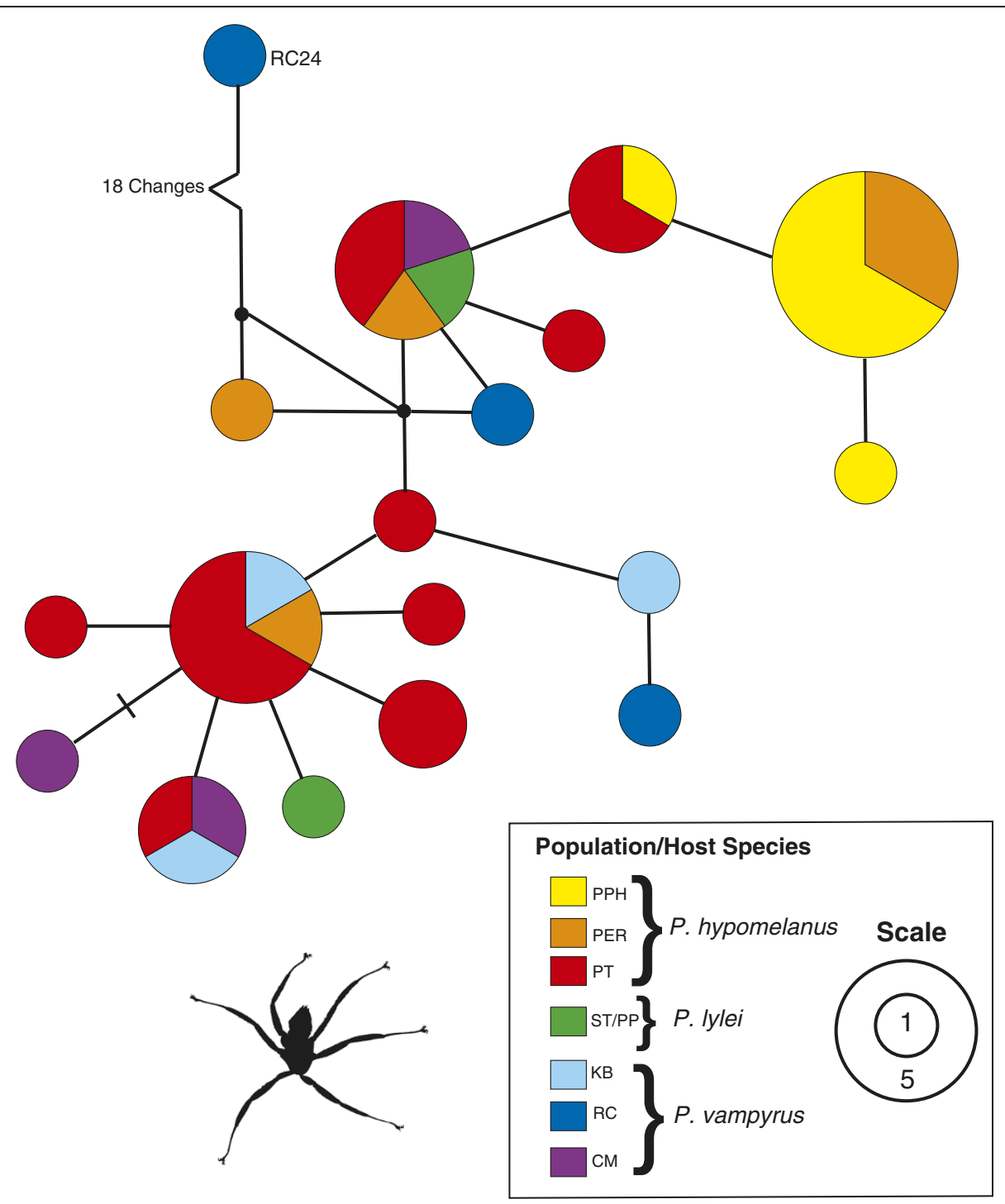

Figure 7 Statistical parsimony network, combined mtDNA dataset, Cyclopodia horsfieldi.

Table 3 Pairwise $F_{S T}$ values (below diagonal) and geographic distances in kilometers (above diagonal) for Cyclopodia horsfieldi populations from Pteropus vampyrus and three $P$. hypomelanus populations

\begin{tabular}{lllll}
\hline & P. vampyrus $^{\mathbf{1}}$ & $\mathrm{PPH}^{2}$ & $\mathrm{PT}^{2}$ & PER $^{2}$ \\
\hline P. vampyrus & - & 170 & 375 & 135 \\
PPH & $0.443^{*}$ & - & 430 & 305 \\
PT & 0.027 & $0.560^{*}$ & - & 375 \\
PER & 0.027 & $0.435^{*}$ & 0.031 & - \\
\hline
\end{tabular}

Data used for Isolation by Distance mantel test.

* Significant based on 1000 permutations; $p<0.05$. Pairwise $F_{S T}$ calculated with complete mtDNA dataset (1744 bp).

${ }^{1} P$. vampyrus from Peninsular Malaysia only, RC and KB pooled.

${ }^{2}$ P. hypomelanus from Pulau Pangkor, PPH; Pulau Tioman, $\mathrm{PT}$; and Pulau Perhentian, PER. populations of Pteropus vampyrus and island populations of $P$. hypomelanus, with the exception of Pulau Pangkor $(\mathrm{PPH})$. These data suggest ongoing or recent gene flow among Cyclopodia horsfieldi parasites between mainland Pteropus vampyrus and eastern P. hypomelanus; and less contact between $P$. vampyrus and the small western island of Pulau Pangkor.

In contrast, Pteropus vampyrus was found to be essentially panmictic across a very large geographic range of thousands of kilometers in Southeast Asia at mtDNA markers [69], and these data were corroborated by satellite telemetry showing regular long-distance dispersal (100 s of kilometers), lack of roost fidelity, and large home range sizes $\left(128,000 \mathrm{~km}^{2}\right)$ across Malaysia, Thailand, and Indonesia [74]. The shallow branching pattern in our ML phylogeny and mixing of haplotypes 
Table 4 Hierarchical analysis of molecular variance (AMOVA) for combined mtDNA dataset (1744bp), Cyclopodia horsfieldi

\begin{tabular}{|c|c|c|c|c|c|c|}
\hline Source of variation & d.f. & S.S. & Variance & Variation \% & Fixation indices & $p$ value \\
\hline Among host species & 2 & 7.51 & 0.008 & 0.4 & $\Phi_{C T}=0.0038$ & 0.445 \\
\hline Among populations within host species & 3 & 16.92 & 0.47 & 22.3 & $\Phi_{S C}=0.224$ & $<0.002$ \\
\hline Within populations & 38 & 61.87 & 1.63 & 77.3 & $\Phi_{\mathrm{ST}}=0.227$ & $<0.001$ \\
\hline
\end{tabular}

Populations grouped within host species, Pteropus hypomelanus (PPH, PT, PER); P. vampyrus (Malaysia, Vietnam); and P. lylei (two individuals, considered one population).

observed in the statistical parsimony network suggest that Cyclopodia horsfieldi populations have recently diverged or are subject to ongoing gene flow. Frequent contact between flying fox host species and subsequent ectoparasite gene flow may best explain the lack of parasite population structure observed. In particular, we suggest that the highly volant Pteropus vampyrus may be acting as a "vector" spreading bat flies to other conspecific populations and Pteropus species in the region during long-distance dispersal events. Satellite telemetry studies have shown that $P$. vampyrus uses small islands as stopover sites when migrating to and from Peninsular Malaysia and Sumatra [74]. We also observed higher nucleotide and haplotype diversity values for flies from $P$. vampyrus relative to those from $P$. hypomelanus. This suggests that populations of Cyclopodia horsfieldi from Pteropus vampyrus may have larger effective population sizes and may be acting as a source for founding island populations of parasites $[12,75]$. In summary, our observations of parasite population structure, combined with prior results from host population genetics and satellite telemetry, lend support to the idea that Pteropus vampyrus is actively dispersing parasites to the outlying island populations of $P$. hypomelanus and making contact, and not vice versa.

Three alternative explanations, beyond host-mediated gene flow of Cyclopodia horsfieldi, may explain our results. First, the observed lack of geographic or host species population genetic structure seen in $C$. horsfieldi could simply be due to invariability or insufficient variance of the molecular markers examined. We suggest this is not the case as a number of previous studies of winged, free-living dipterans using the same markers at similar geographic scales have found significant geographic population structure [36-39,76]. All else being equal, free-living, volant flies should have lower levels of population genetic subdivision than parasites almost wholly dependent on their hosts for dispersal (i.e. bat flies). Second, endosymbionts, e.g. Wolbachia or Arsenophonus, may have influenced the observed lack of population structure and genetic variation via mitochondrial sweeps, as seen in other dipteran species $[34,39,77,78]$. Differences in Wolbachia infection and immunity can create striking differences in mtDNA diversity and lead to speciation, e.g. in fig wasps [79]. A number of novel endosymbiont lineages have been identified in bat flies [80-82], and previous studies have suggested that selective sweeps caused by these endosymbionts may explain a lack of mtDNA diversity in bat flies [34]. While we cannot rule out this possibility, it seems unlikely that this selective pressure has influenced the demographic history of each bat fly population sampled. Also, even in the case of Wolbachia infection in insects, high levels of migration may still be a more prominent factor reducing genetic differentiation in species with potential to disperse long distances [83]. Third, demographic factors, i.e. populations bottlenecks with subsequent expansion, could also explain a lack of genetic variation and phylogeographic structure in Cyclopodia horsfieldi [84]. This scenario also seems unlikely, as it also would have to occur independently across multiple geographic localities for each sampled population. The association between Cyclopodia spp. and their flying fox hosts is likely not recent [16], and we believe that high gene flow among parasites is the most parsimonious explanation for the observed results.

\section{Implications for zoonotic disease ecology}

Bats are important reservoir hosts for a large number of emerging zoonotic viruses [85], including neurotropic viruses with high mortality rates in the genus Henipavirus [86,87]. Nipah virus (NiV) caused significant human mortality ( 40\%) during its initial outbreak in Malaysia in 1998 [88], and has emerged repeatedly in Bangladesh and India since 2001 [89-91]. The bat species examined here, Pteropus vampyrus, P. lylei, and P. hypomelanus are considered three of the most important natural reservoir hosts for this virus [92-94]. The low levels of population differentiation observed in Cyclopodia horsfieldi, suggest high levels of contact among Pteropus species in Southeast Asia - a pattern not apparent from host genealogy or prior ecological studies alone.

The data we present here on host specificity also contributes to a better understanding of interspecific contact between Pteropus species in Southeast Asia, and also potentially with other fruit bat species not sampled here. Two individuals of the fly Eucampsipoda sundaica 
were collected from Pteropus vampyrus in Kuala Berang, Malaysia. This is an ectoparasite species most commonly associated with Eonycteris spelaea, a cave-dwelling, nectivorous bat species in Malaysia [24], but also known from fruit bats in the genera Cynopterus and Rousettus $[59,73]$. This suggests that physical contact between Pteropus spp. and other Pteropodid species with different roosting ecologies may occur on occasion, potentially during interactions over shared food resources [95]. For example, in Bangladesh physical contact between Pteropus giganteus, Rousettus leschenaultii, and Cynopterus brachyiotis was observed with infrared cameras at shared date palm sap feeding sites [96]. This supports observations from serological studies of $\mathrm{NiV}$ in Malaysia in which neutralizing antibodies to $\mathrm{NiV}$ were detected in the sera of 5\% (2/38) of Eonycteris spelaea [97]. Similarly, 3.5\% (2/56) of Cynopterus brachyotis individuals were also positive for NiV antibodies in these surveys [97]. These results were presumed to represent rare instances of cross-species NiV spillover from Pteropus spp., and fit with our observations of occasional ectoparasite sharing between these species.

We also observed one genetically divergent fly, RC24, that could represent a morphologically indistinguishable male of the sister species to Cyclopodia horsefeldi, C. ferrarii. More specimens of bat flies, especially females, collected from Pteropus vampyrus should be examined in the future to see if this truly represents Cyclopodia ferrarii and another case of parasite host switching between bat species - this time between Pteropus vampyrus and $P$. giganteus. Horizontal transfer of bat flies between sympatric fruit bat species deserves further research attention, as results are relevant for understanding the mechanism of cross-species viral spillover and maintenance of diseases amongst reservoir host species. NiV has a short infectious period and long-term immunity in bats, suggesting that very large populations, or metapopulation dynamics, are necessary to sustain the virus in bat reservoirs [98-100]. Host species contact inferred here using ectoparasite population genetic structure may provide insight as to how NiV can be maintained in some bat populations with relatively small census sizes, e.g. Pteropus hypomelanus [101], and why it may be so widespread among Pteropus spp in the region [92-94,102].

\section{Bat flies as potential vectors for bat pathogens}

Other diseases endemic in bat populations, such as apicomplexan parasites, may not cause significant morbidity or mortality to their hosts, but have evolved longterm co-evolutionary relationships with them [103]. Malaria parasites (Hepatocystis sp.) were identified using morphological and molecular methods from the same population of Pteropus hypomelanus sampled here [104].
The role of bat flies in the potential transmission of bat malarial parasites is not clear. Earlier studies failed to find evidence for Hepatocystis infection in bat flies [105-107], and only Culicoides sp. midges have been demonstrated to be competent vectors for these parasites [108]. More recently, oocysts of the parasite, Plasmodium murinus, were found in 7 of 26 dissected Nycteribia kolenatii from Myotis daubentoni bats [109]. Electron microscopy of the salivary glands of these flies confirmed the presence of sporozoites [109] which suggests possible transmission of malarial parasites by nycteribiids. If bat flies are suitable vectors for Hepatocystis and other related parasites, and if they move regularly between fruit bat populations and species (as demonstrated here) this could disrupt expected coevolutionary patterns between chiropteran hosts and their malarial parasites.

Bat flies also play an important role in the evolution and transmission of Bartonella spp. in bats globally [110]. There is some evidence for long-term coevolutionary patterns between bat flies and their Bartonella parasites [110]. For example, gltA genotypes of Bartonella from Cyclopodia greefi flies collected from $\mathrm{Ei}$ dolon helvum (Family Pteropodidae) in Ghana grouped closely with Bartonella genotypes from related Cyclopodia horsfieldi flies sampled from Pteropus hypomelanus in Malaysia, suggesting an underlying cophylogenetic pattern for Bartonella-bat-bat fly associations [110]. Additional studies on bat fly population structure, dispersal, ecology and host specificity will help to clarify the role of bat hosts vs. bat ectoparasites/vectors in the evolution and ecology of Bartonella $[110,111]$.

\section{Conclusions}

For the first time, we investigate the population genetic structure of an Old World bat fly species, Cyclopodia horsfieldi, and show it to be a useful tool to understand host movement and interspecific contact among bat species. We observed an overall lack of morphological variation and phylogenetic structure across geographic regions and host species for $C$. horsfieldi. For some bat fly populations, elevated pairwise genetic differentiation $\left(\mathrm{F}_{\mathrm{ST}}\right)$ did correspond to a lack of gene flow in host populations, i.e. insular populations of $P$. hypomelanus in Malaysia. By combining our data with previous studies of bat genetics, telemetry, and parasite host range, we suggest that $P$. vampyrus may facilitate movement of bat flies through frequent physical contact among the three Pteropus species in the region, and occasionally with other fruit bat species. Our approach and findings have wide implications for understanding zoonotic disease dynamics and cross-species transmission in bats, in particular the transmission and ecology of Nipah virus. Bat 
flies may also play a critical role in bat disease transmission and evolution (e.g. Bartonella or apicomplexan parasites), and their ecology, dispersal, and competence as vectors of bacterial and/or viral pathogens are in need of further investigation.

\section{Competing interests}

The authors declare that they have no competing interests.

\section{Authors' contributions}

$\mathrm{KJO}$ lead and implemented the sample collection, laboratory work, molecular analysis, and writing of the manuscript. CWD examined the morphology for all specimens and helped to draft the manuscript. KD examined specimens and helped to revise the manuscript. JCM, DM, NBS, SLP, PD, and RD assisted in the study design, project coordination, analysis, and manuscript revisions; NBS additionally helped collect specimens on Pulau Perhentian, Malaysia. All authors read and approved the final manuscript.

\section{Authors' information}

Dr. Olival is currently a Senior Research Scientist at EcoHealth Alliance. His research focuses on understanding the drivers of zoonotic disease emergence and the ecology and evolution of bats, their associated parasites and viruses. This study was part of his dissertation research at Columbia University with the laboratory work completed at the Sackler Institute for Comparative Genomics at the American Museum of Natural History.

\section{Acknowledgements}

We thank J.H. Epstein, T. Hughes, J. Westrum, J. Zambruski, K. Abdul, S.A. Rahman, and staff at the Veterinary Research Institute for assistance with field work in Malaysia. Malaysia sampling was conducted under a permit from the Economic Planning Unit (No. 1156) with permission from PERHILITAN. N.T. Son and Mr. Tien and staff at the Institute for Ecology and Biological Resources, Hanoi for assistance in the field in Vietnam. J. Walson and staff at the Wildlife Conservation Society for support in Cambodia. Interns M. Ahn and T. Hudson for assistance in the lab. L. Esposito for taking photos used in Figure 2. A. Dowling for identification of mites. Participation of NBS in fieldwork was supported by the Taxonomic Mammalogy fund at the American Museum of Natural History. KJO was supported by funding from an EPA STAR Fellowship (\#FP-91638101-0), Bat Conservation International, Lubee Bat Conservancy, Columbia University's Center for Environmental Research and Conservation and the Department of Ecology, Evolution, and Environmental Biology, and a National Institutes of Health/ National Science Foundation 'Ecology of infectious diseases award' (R01TW05869). KJO is currently supported by an NIAID non-biodefense EID Research Opportunities Award (1 R01 Al079231-01).

\section{Author details \\ ${ }^{1}$ EcoHealth Alliance, New York, NY 10001, USA. ${ }^{2}$ Sackler Institute for Comparative Genomics, American Museum of Natural History, New York, NY 10024, USA. ${ }^{3}$ Department of Ecology, Evolution, and Environmental Biology, Columbia University, New York, NY 10027, USA. ${ }^{4}$ Department of Biology, Western Kentucky University, Bowling Green KY 42101, USA. ${ }^{5}$ Department of Zoology, Field Museum of Natural History, Chicago, IL 60605, USA. ${ }^{6}$ Department of Mammalogy, American Museum of Natural History, New York, NY 10024, USA. ${ }^{7}$ Global Footprint Network, Oakland, CA 94607, USA. ${ }^{8}$ Department of Biological Sciences, State University of New York at Buffalo, Buffalo, NY 14260, USA.}

Received: 17 June 2013 Accepted: 6 August 2013 Published: 8 August 2013

\section{References}

1. Nieberding CM, Olivieri l: Parasites: proxies for host genealogy and ecology? Trends Ecol Evol 2007, 22(3):156-165.

2. Poulin R: Evolutionary ecology of parasites. 2nd edition. Princeton, NJ: Princeton University Press; 2007

3. Dybdahl M, Lively C: The geography of coevolution: comparative population structures for a snail and its trematode parasite. Evolution 1996, 50:2264-2275.
4. Light JE, Hafner MS: Cophylogeny and disparate rates of evolution in sympatric lineages of chewing lice on pocket gophers. Mol Phylogen Evol 2007, 45(3):997-1013.

5. McCoy KD, Boulinier T, Tirard C: Comparative host-parasite population structures: disentangling prospecting and dispersal in the black-legged kittiwake Rissa tridactyla. Mol Ecol 2005, 14(9):2825-2838.

6. Nieberding C, Morand S, Libois R, Michaux JR: A parasite reveals cryptic phylogeographic history of its host. Proc Royal Soc London Series B-Biol Sci 2004, 271(1557):2559-2568.

7. Whiteman NK, Kimball RT, Parker PG: Co-phylogeography and comparative population genetics of the threatened Galapagos hawk and three ectoparasite species: ecology shapes population histories within parasite communities. Mol Ecol 2007, 16:4759-4773.

8. Biek R, Drummond AJ, Poss M: A virus reveals population structure and recent demographic history of its carnivore host. Science 2006, 311(5760):538-541.

9. Brant SV, Orti G: Evidence for gene flow in parasitic nematodes between two host species of shrews. Mol Ecol 2003, 12(10):2853-2859.

10. Gomez-Diaz E, Gonzalez-Solis J, Peinado MA, Page RDM: Lack of hostdependent genetic structure in ectoparasites of Calonectris shearwaters. Mol Ecol 2007, 16(24):5204-5215.

11. Nadler SA: Microevolution and the genetic-structure of parasite populations. J Parasitol 1995, 81(3):395-403.

12. Nieberding C, Morand S, Libois R, Michaux JR: Parasites and the island syndrome: the colonization of the western Mediterranean islands by Heligmosomoides polygyrus (Dujardin, 1845). J Biogeogr 2006, 33(7):1212-1222.

13. Bruyndonckx N, Biollaz F, Dubey S, Goudet J, Christe P: Mites as biological tags of their hosts. Mol Ecol 2010, 19(13):2770-2778.

14. Dittmar K, Porter ML, Murray S, Whiting MF: Molecular phylogenetic analysis of nycteribiid and streblid bat flies (Diptera: Brachycera, Calyptratae): Implications for host associations and phylogeographic origins. Mol Phylogen Evol 2006, 38(1):155.

15. Dick CW, Patterson BD: Bat flies -- obligate ectoparasites of bats. In Micromammals and Macroparasites: From evolutionary ecology to management. Edited by Morand S, Krasnov BR, Poulin R. New York: Springer; 2006:179-194.

16. Theodor O: Revision of the genus Cyclopodia (Nycteribiidae, Diptera). Parasitology 1959, 49(1-2):242-308.

17. Farafonova GV, Kruskop SV: Notes on the Nycteribiidae (Diptera) of Viet Nam. Dipterol Res 2001, 12(1):29-31.

18. Dick CW: High host specificity of obligate ectoparasites. Ecol Entomol 2007, 32(5):446-450

19. Dick CW, Patterson BD: Against all odds: explaining high host specificity in dispersal-prone parasites. Int J Parasitol 2007, 37:871-876.

20. Peterson BV, Durden LA, Keirans JE, Taylor PM: Some Ectoparasites of Bats from Halmahera Island. Indonesia. Entomol News 1990, 101(1):39-47.

21. Marshall AG: The Ecology of Ectoparasitic Insects. London: Academic; 1981.

22. Patterson BD, Ballard JWO, Wenzel RL: Distributional evidence for cospeciation between neotropical bats and their bat fly ectoparasites. Stud Neotrop Fauna Environ 1998, 33(2-3):76-84.

23. ter Hofstede HM, Fenton MB, Whitaker JO: Host and host-site specificity of bat flies (Diptera: Streblidae and Nycteribiidae) on Neotropical bats (Chiroptera). Can J Zool-Revue Can De Zool 2004, 82(4):616-626.

24. Ching LM, Marshall AG: The breeding biology of the bat-fly Eucampsipoda sundaicum Theodor, 1955 (Diptera: Nycteribiidae). Malay Nat J 1968, 21:171-180.

25. Marshall AG: Life Cycle of Basilia hispida Theodor 1967 (DipteraNycteribiidae) in Malaysia. Parasitology 1970, 61:1-19.

26. Kunz TH, Jones DP: Pteropus vampyrus. Mammalian Species 2000, 642:1-6.

27. Koopman KF: Distributional patterns of Indo-Malayan bats (Mammalia: Chiroptera). Am Mus Novit 1989, 2942:1-20.

28. Jones DP, Kunz TH: Pteropus hypomelanus. Mammalian Species 2000, 639:1-6.

29. Corbet GB, Hill JE: The Mammals of the Indomalayan Region: A systematic review. London: Natural History Museum Publications Oxford University Press; 1992.

30. Koopman KF: Chiroptera: systematics. Handbook of zoology: a natural history of the phyla of the animal kingdom, Volume 8. New York; 1994.

31. Giannini N, Almeida FC, Simmons NB, Helgen KM: The systematic position of Pteropus leucopterus and its bearing on the monophyly and 
relationships of Pteropus (Chiroptera: Pteropodidae). Acta Chiropt 2008, 10(1):11-20

32. Petersen FT, Meier R, Kutty SN, Wiegmann BM: The phylogeny and evolution of host choice in the Hippoboscoidea (Diptera) as reconstructed using four molecular markers. Mol Phylogen Evol 2007, 45:111-122.

33. Wilson GM, Byrd KS, Caire W, Bussche RAVD: Lack of Population Genetic Structure in the Bat Fly (Trichobius major) in Kansas, Oklahoma, and Texas based on DNA Sequence Data for the Cytochrome Oxidase I (COI) and NADH Dehydrogenase 4 (ND4) Genes. Proc Okla Acad Sci 2007, 87:31-36.

34. Lack JB, Nichols RD, Wilson GM, Van Den Bussche RA: Genetic Signature of Reproductive Manipulation in the Phylogeography of the Bat Fly, Trichobius major. J Hered 2011, 102(6):705-718.

35. Epstein JH, Zambriski JA, Rostal MK, Heard DJ, Daszak P: Comparison of Intravenous Medetomidine and Medetomidine/Ketamine for Immobilization of Free-Ranging Variable Flying Foxes (Pteropus hypomelanus). PLOS ONE 2011, 6(10):e25361.

36. Dittmar K, Whiting MF: Genetic and phylogeographic structure of populations of Pulex simulans (Siphonaptera) in Peru inferred from two genes (CytB and Coll ). Parasitol Res 2003, 91:55-59.

37. MacDonald C, Brookfield JFY: Intraspecific molecular variation in the seaweed fly Coelopa frigida consistent with behavioural distinctness of British and Swedish populations. Mol Ecol 2002, 11:1637-1646.

38. Tothova A, Bryja J, Bejdak P, Vanhara J: Molecular markers used in phylogenetic studies of Diptera with a methodological overview. Acta Univ Carol Biol 2006, 50(1-2):125-133.

39. Baudry E, Bartos J, Emerson K, Whitworth T, Werren JH: Wolbachia and genetic variability in the birdnest blowfly Protocalliphora sialia. Mol Ecol 2003, 12(7):1843-1854.

40. Maekawa K, Kitade O, Matsumoto T: Molecular phylogeny of orthopteroid insects based on the mitochondrial cytochrome oxidase II gene. Zool Sci 1999, 16:175-184.

41. Hebert PDN, Penton EH, Burns JM, Janzen DH, Hallwachs W: Ten species in one: DNA barcoding reveals cryptic species in the newtropical skipper butterfly Astraptes fulgerator. Proc Natl Acad Sci U S A 2004, 101:14812-14817.

42. Oliveira MT, Da Rosa AC, Azeredo-Espin AML, Lessinger AC: Improving access to the control region and tRNA gene clusters of Dipteran mitochondrial DNA. J Med Entomol 2006, 43(3):636-639.

43. Katoh K, Kuma K, Toh H, Miyata T: MAFFT version 5: improvement in accuracy of multiple sequence alignment. Nucleic Acids Res 2005 33(2):511-518

44. Maddison DR, Maddison WP: MACCLADE 4: Analysis of Phylogeny and Character Evolution, Version 4.08. Sunderland, Massachusetts: Sinauer Associates; 2006

45. Swofford DL: PAUP*: Phylogenetic Analysis Using Parsimony (*and other methods). Sunderland, MA: Sinauer Associates; 2000.

46. Stamatakis A: RAxML-VI-HPC: Maximum likelihood-based phylogenetic analyses with thousands of taxa and mixed models. Bioinformatics 2006, 22(21):2688-2690.

47. Ronquist F, Teslenko M, van der Mark P, Ayres DL, Darling A, Hohna S, Larget B, Liu L, Suchard MA, Huelsenbeck JP: MrBayes 3.2: efficient Bayesian phylogenetic inference and model choice across a large model space. Syst Biol 2012, 61(3):539-542.

48. Felsenstein J: Confidence-Limits on Phylogenies - an Approach Using the Bootstrap. Evolution 1985, 39(4):783-791.

49. Posada D, Crandall KA: Modeltest: testing the model of DNA substitution. Bioinformatics 1998, 14(9):817-818.

50. Nylander JA, Wilgenbusch JC, Warren DL, Swofford DL: AWTY (are we there yet?): a system for graphical exploration of MCMC convergence in Bayesian phylogenetics. Bioinformatics 2008, 24(4):581-583.

51. Clement M, Posada D, Crandall KA: TCS: a computer program to estimate gene genealogies. Mol Ecol 2000, 9(10):1657-1660

52. Nei M: Molecular evolutionary genetics. New York: Columbia University Press; 1987.

53. Rozas J, Sanchez-DelBarrio JC, Messeguer X, Rozas R: DnaSP, DNA polymorphism analyses by the coalescent and other methods. Bioinformatics 2003, 19(18):2496-2497.

54. Slatkin M: Inbreeding Coefficients and Coalescence Times. Genet Res 1991, 58(2):167-175
55. Mantel N: The detection of disease clustering and a generalized regression approach. Cancer Res 1967, 27:209-220.

56. Jombart $\mathrm{T}$ : adegenet: a $\mathrm{R}$ package for the multivariate analysis of genetic markers. Bioinformatics 2008, 24(11):1403-1405.

57. Excoffier L, Smouse PE, Quattro JM: Analysis Of Molecular Variance Inferred From Metric Distances Among DNA Haplotypes - Application To Human Mitochondrial-DNA Restriction Data. Genetics 1992, 131(2):479-491.

58. Schneider S, Roessli D, Excoffier L: Arlequin: A software for population genetics data analysis. 20th edition. University of Geneva: Department of Anthropology Genetics and Biometry Lab; 2000.

59. Theodor O: On the genus Eucampsipoda, Kol and Dipseliopoda, n.g. (Nycteribiidae, Diptera). Parasitology 1955, 45:195-229.

60. Domrow R: New and little known Laelaptidae, Trombiculidae and Listrophoridae (Acarina) from Australasian mammals. Proc Linnean Soc NSW 1961, 86:60-95.

61. Valim MP, Gazeta GS: Phoretic association of the mites Myialges anchora Sergent \& Trouessart (Acaridida, Epidermoptidae) and Ornithocheyletia hallae smiley (Actinedida, Cheyletiellidae) with Pseudolynchia canariensis (Macquart) (Diptera, Hippoboscidae). Rev Bras Entomol 2007, 51:518-519.

62. Asbakk K: Mites (Acari) on mosquitoes in Finnmark, northern Norway. Fauna (Oslo) 2005, 58(2):50-53.

63. Macchioni F, Magi M, Mancianti F, Perrucci S: Phoretic association of mites and mallophaga with the pigeon fly Pseudolynchia canariensis. Parasite-J De La Soc Fr De Parasitol 2005, 12(3):277-279.

64. Chen B, Harbach RE, Walton C, He ZB, Zhong DB, Yan GY, Butlin RK: Population genetics of the malaria vector Anopheles aconitus in China and Southeast Asia. Infect Genet Evol 2012, 12(8):1958-1967.

65. Li Y, Wu Y, Chen H, Wu J, Li Z: Population structure and colonization of Bactrocera dorsalis (Diptera: Tephritidae) in China, inferred from mtDNA COI sequences. J Appl Entomol 2012, 136(4):241-251.

66. Ruiz-Arce R, Barr NB, Owen CL, Thomas DB, McPheron BA: Phylogeography of Anastrepha obliqua Inferred With mtDNA Sequencing. J Econ Entomol 2012, 105(6):2147-2160.

67. Cha SY, Yoon HJ, Lee EM, Yoon MH, Hwang JS, Jin BR, Han YS, Kim I: The complete nucleotide sequence and gene organization of the mitochondrial genome of the bumblebee, Bombus ignitus (Hymenoptera : Apidae). Gene 2007, 392(1-2):206-220.

68. Shao R, Barker SC: Mitochondrial genomes of parasitic arthropods: implications for studies of population genetics and evolution. Parasitology 2007, 134:153-167.

69. Olival KJ: Population genetic structure and phylogeography of Southeast Asian flying foxes: implications for conservation and disease ecology. New York: Columbia University; 2008.

70. Dick CW, Patterson BD: An excess of males: skewed sex ratios in bat flies (Diptera : Streblidae). Evol Ecol 2008, 22(6):757-769.

71. Dittmar K, Morse S, Gruwell M, Mayberry J, DiBlasi E: Spatial and temporal complexities of reproductive behavior and sex ratios: a case from parasitic insects. PLOS ONE 2011, 6(5):e19438.

72. Overal WL: Host-relations of the Batfly Megistopoda aranea (Diptera: Streblidae) in Panama. Univ Kansas Sci Bull 1980, 52:1-20.

73. Zabat AG, Eduardo SL: Some Ectoparasites of the Common Rousette Bat (Rousettus amplexicaudatus Geofroy, 1810) (Mammalia: Chiroptera: Pteropodidae) from Colonies in Batangas and Rizal, Philippines. Philipp J Vet Med 2011, 48(1):53-56.

74. Epstein JH, Olival KJ, Pulliam JRC, Smith C, Westrum J, Hughes T, Dobson AP, Zubaid A, Rahman SA, Basir MM, et al: Pteropus vampyrus, a hunted migratory species with a multinational home-range and a need for regional management. J Appl Ecol 2009, 46(5):991-1002.

75. Hartl DL, Clark AG: Principles of Population Genetics. Sunderland, Massachusetts: Sinauer Associates, Inc.; 1997

76. Hasan AU, Suguri S, Fujimoto C, Itaki RL, Harada M, Kawabata M, Bugoro H, Albino B, Tsukahara T, Hombhanje F, et al: Phylogeography and dispersion pattern of Anopheles farauti senso stricto mosquitoes in Melanesia. Mol Phylogen Evol 2008, 46(2):792-800.

77. Hurst GDD, Jiggins FM: Problems with mitochondrial DNA as a marker in population, phylogeographic and phylogenetic studies: the effects of inherited symbionts. Proc Royal Soc B-Biol Sci 2005, 272(1572):1525-1534.

78. Charlat S, Hurst GDD, Mercot H: Evolutionary consequences of Wolbachia infections. Trends Genet 2003, 19(4):217-223. 
79. Xiao JH, Wang NX, Murphy RW, Cook J, Jia LY, Huang DW: Wolbachia infection and dramatic intraspecific mitochondrial dna divergence in a fig wasp. Evolution 2012, 66(6):1907-1916.

80. Morse SF, Dick CW, Patterson BP, Dittmar K: Some like it hot: Evolution and ecology of novel endosymbionts in bat flies of cave roosting bats (Hippoboscoidea, Nycterophiliinae). App/ Environ Microbiol 2012, 78:8639-8649.

81. Hosokawa T, Nikoh N, Koga R, Sato M, Tanahashi M, Meng XY, Fukatsu T: Reductive genome evolution, host-symbiont co-speciation and uterine transmission of endosymbiotic bacteria in bat flies. Isme Journal 2012 6(3):577-587.

82. Morse SF, Bush SE, Patterson BD, Dick CW, Gruwell ME, Dittmar K: Evolution, Multiple Acquisition, and Localization of Endosymbionts in Bat Flies (Diptera: Hippoboscoidea: Streblidae and Nycteribiidae). Appl Environ Microbiol 2013, 79(9):2952-2961.

83. Graham RI, Wilson K: Male-killing Wolbachia and mitochondrial selective sweep in a migratory African insect. BMC Evol Biol 2012, 12:204.

84. Frankham R, Lees K, Montgomery M: Do population size bottlenecks reduce evolutionary potential? Anim Conserv 1999, 2:255-260.

85. Olival KJ, Epstein JH, Wang LF, Field HE, Daszak P: Are bats unique viral reservoirs? In New Directions in Conservation Medicine: Applied Cases of Ecological Health. 2nd edition. Edited by Aguirre AA, Ostfeld RS, Daszak P. Oxford: Oxford University Press; 2012:195-212.

86. Daszak P, Plowright R, Epstein JH, Pulliam JH, Abdul Rahman S, Field HE, Smith CS, Olival KJ, Luby S, Halpin K, et al: The emergence of Nipah and Hendra virus: pathogen dynamics across a wildlife-livestock-human continuum. In Disease Ecology: Community structure and pathogen dynamics. Edited by Collinge S, Ray C. Oxford: Oxford University Press; 2006:188-203.

87. Olival KJ, Daszak P: The ecology of emerging neurotropic viruses. J Neurovirol 2005, 11:440-445.

88. Chua KB, Bellini WJ, Rota PA, Harcourt BH, Tamin A, Lam SK, Ksiazek TG, Rollin PE, Zaki SR, Sheih WJ, et al: Nipah virus: a recently emergent deadly paramyxovirus. Science 2000, 288:1432-1435.

89. Luby SP, Hossain MJ, Gurley ES, Ahmed BN, Banu S, Khan SU, Homaira N, Rota PA, Rollin PE, Comer JA, et al: Recurrent zoonotic transmission of nipah virus into humans, Bangladesh, 2001-2007. Emerging Infect Dis 2009, 15(8):1229-1235.

90. Lo MK, Lowe L, Hummel KB, Sazzad HMS, Gurley ES, Hossain MJ, Luby SP, Miller DM, Comer JA, Rollin PE, et al: Characterization of Nipah Virus from Outbreaks in Bangladesh, 2008-2010. Emerging Infect Dis 2012, 18(2):248-255.

91. WHO: Nipah virus. http://www.who.int/mediacentre/factsheets/fs262/en/ 2013.

92. Chua KB, Koh CL, Hooi PS, Wee KF, Khong JH, Chua BH, Chan YP, Lim ME, Lam SK: Isolation of Nipah virus from Malaysian Island flying-foxes. Microb Infect 2002, 4:145-151.

93. Rahman SA, Hassan SS, Olival KJ, Mohamed M, Chang L-Y, Hassan L, Suri AS, Saad NM, Shohaimi SA, Mamat ZC, et al: Characterization of Nipah Virus from Naturally Infected Pteropus vampyrus Bats, Malaysia. Emerging Infectious Disease 2010, 16(12):1990-1993.

94. Wacharapluesadee S, Lumlertdacha B, Boongird K, Wanghongsa S, Chanhome L, Rollin P, Stockton P, Rupprecht CE, Ksiazek TG, Hemachudha T: Bat Nipah Virus, Thailand. Emerging Infect Dis 2005, 11(12):1949-1951.

95. Hodgkison R, Balding ST, Zubaid A, Kunz TH: Temporal variation in the relative abundance of fruit bats (Megachiroptera : Pteropodidae) in relation to the availability of food in a lowland malaysian rain forest. Biotropica 2004, 36(4):522-533.

96. Khan MSU, Hossain J, Gurley ES, Nahar N, Sultana R, Luby SP: Use of Infrared Camera to Understand Bats' Access to Date Palm Sap: Implications for Preventing Nipah Virus Transmission. Ecohealth 2011, 7(4):517-525.

97. Yob JM, Field H, Rashdi AM, Morrissy C, Heide B, Rosta P, Adzhar A, White J, Daniels $P$, Jamaluddin A, et al: Nipah virus infection in bats (Order Chiroptera) in Peninsular Malaysia. Emerging Infect Dis 2001, 7(3):439-441.

98. Plowright RK, Field HE, Smith C, Divljan A, Palmer C, Tabor G, Daszak P, Foley JE: Reproduction and nutritional stress are risk factors for Hendra virus infection in little red flying foxes (Pteropus scapulatus). Proceedings of the Royal Society B-Biological Sciences 2008, 275:861-869.
99. Halpin K, Hyatt AD, Plowright RK, Epstein JH, Daszak P, Field HE, Wang LF, Daniels PW, Henipavirus Ecology Res G: Emerging viruses: Coming in on a wrinkled wing and a prayer. Clin Infect Dis 2007, 44(5):711-717.

100. Breed A, Field H, Plowright R: Volant viruses: a concern to bats, humans and other animals. Microbiology Australia 2005:59-62.

101. Rahman SA, Hassan L, Epstein JH, Mamat ZC, Yatim AM, Hassan SS, Field HE, Hughes T, Westrum J, Naim MS, et al: Risk factors for Nipah virus infection among pteropid bats, Peninsular Malaysia. Emerging Infect Dis 2013, 19:51. Internet.

102. Epstein JH, Prakash V, Smith CS, Daszak P, McLaughlin AB, Meehan G, Field $H E$, Cunningham AA: Henipavirus infection in fruit bats (Pteropus giganteus), India. Emerging Infect Dis 2008, 14(8):1309-1311.

103. Garnham PCC: Hepatocystis of bats and squirrels. In Malaria Parasites and other Haemosporidia. Oxford: Blackwell Scientific; 1966.

104. Olival KJ, Stiner EO, Perkins SL: Detection of Hepatocystis sp. in Southeast Asian Flying Foxes (Pteropodidae) using Microscopic and Molecular Methods. J Parasitol 2007, 93(6):1538-1540.

105. Bearup AJ, Lawrence JJ: A search for the vector of Plasmodium pteropi Breinl. Proceedings of the Linnean Society NSW 1947, 71:197-200.

106. Garnham PCC: An Attempt To Find The Vector Of Hepatocystis (=Plasmodium) Kochi (Levaditi And Schoen). Exp Parasitol 1951, 1(1):94-107.

107. McGhee RB: The occurrence of bat malaria in the New Hebrides and Phillipine Islands. J Parasitol 1949, 35(5):545.

108. Garnham PC, Ikata M, Minter DM, Heisch RB, Phipps JD: Culicoides Adersi Ingram And Macfie, 1923, A Presumed Vector Of Hepatocystis (=Plasmodium) Kochi (Laveran,1899). Nature 1961, 190(477):739.

109. Gardner RA: A malarial parasite of bats. Inst Terrestrial Ecol Ann Rep 1985, 1984:125-126

110. Morse SF, Olival KJ, Kosoy M, Billeter SA, Patterson BD, Dick CW, Dittmar K: Global distribution and genetic diversity of Bartonella in bat flies (Hippoboscoidea, Streblidae, Nycteribiidae). Infect Genet Evol 2012, 12(8):1717-1723.

111. Bai Y, Kosoy M, Recuenco S, Alvarez D, Moran D, Turmelle A, Ellison J, Garcia $\mathrm{DL}$, Estevez A, Lindblade K, et al: Bartonella spp. in Bats, Guatemala. Emerging Infect Dis 2011, 17(7):1269-1272.

doi:10.1186/1756-3305-6-231

Cite this article as: Olival et al:: Lack of population genetic structure and host specificity in the bat fly, Cyclopodia horsfieldi, across species of Pteropus bats in Southeast Asia. Parasites \& Vectors 2013 6:231.

\section{Submit your next manuscript to BioMed Central and take full advantage of:}

- Convenient online submission

- Thorough peer review

- No space constraints or color figure charges

- Immediate publication on acceptance

- Inclusion in PubMed, CAS, Scopus and Google Scholar

- Research which is freely available for redistribution

Submit your manuscript at www.biomedcentral.com/submit
C) BioMed Central 